\title{
Na-Metasomatism and Uranium Mineralization during a Two-Stage Albitization at Kitongo, Northern Cameroon: Structural and Geochemical Evidence
}

\author{
Arnaud Patrice Kouske ${ }^{1 *}$, Cheo Emmanuel Suh ${ }^{2}$, Richard Tanwi Ghogomu ${ }^{1}$, Vincent Ngako $^{3}$ \\ ${ }^{1}$ Laboratory of Applied Geology-Metallogeny, Department of Earth Sciences, University of Yaoundé 1, Yaoundé, Cameroon \\ ${ }^{2}$ Economic Geology Unit, Department of Geology and Environmental Science, University of Buea, Buea, Cameroon \\ ${ }^{3}$ Mega Uranium Corporation Cameroon PLC, Yaoundé, Cameroon \\ Email: "pathpatrice@yahoo.fr
}

Received September 16, 2011; revised November 21, 2011; accepted December 25, 2011

\begin{abstract}
Mapping and documentation of lithological varieties and their corresponding geochemistry at the Kitongo uranium mineralization were concerned. The Kitongo U occurrence is hosted by granitic rocks that include interleaved sequences of metasedimentary and metavolcanic rocks of the collectively termed Poli Group. U-mineralization and Na-metasomatism are related and structurally controlled. The most promising uraniferous bodies are intimately related to intersecttions between the ductile ENE-trending faults and the brittle conjugate R' faults postdating the shearing event. The concentration of uranium at fault intersections rather than along individual faults suggests that these zones that are dilatational in nature were also highly permeable and therefore the hydrothermal fluids ponded there could readily precipitate $\mathrm{U}$ therein. A two-stage albitization has altered the foliated granitic host rock and the second albitization that has overprinted the first one is more effective at fault intersections. Whole rock geochemistry was performed by using ICP-MS and ICP-AES respectively for major oxides, trace and REE. The U-bearing rock suite exhibits restricted range in $\mathrm{SiO}_{2}$ concentration $(62.89 \%-70.91 \%)$ and $\mathrm{Al}_{2} \mathrm{O}_{3}(13.16 \%-18.59 \%)$ and it is poor in $\mathrm{MgO}(0.02 \%-1.03 \%), \mathrm{CaO}(0.24 \%-$ $1.88 \%)$ and $\mathrm{K}_{2} \mathrm{O}(0.08 \%-5.32 \%)$. The mineralized rocks are however comparatively richer in $\mathrm{Na}_{2} \mathrm{O}(4.33 \%-10.92 \%)$ compared to their barren counterparts. The host granite and associated granodioritic rocks in the area are weakly metaluminous, peralkaline, and are calc-alkaline. They are moderately to strongly fractionated and have tholeiitic and shoshonitic affinities with moderate to high HFSE (high field strength elements) and LILE (large ion lithophile elements) enrichment. The $\mathrm{Rb} / \mathrm{Sr}, \mathrm{Rb} / \mathrm{Ba}$ and $\mathrm{Sr} / \mathrm{Ba}$ ratios are $0.31,0.14$ and 1.48 , respectively. $\mathrm{U}$ content in the mineralized granite is up to $651 \mathrm{ppm}$ while the non-mineralized rock has only $2.4 \mathrm{ppm} \mathrm{U}$. The REE patterns of the granite show LREE enrichment and strong Eu negative anomalies $\left(\mathrm{Eu} / \mathrm{Eu}^{*}=0.03\right.$ to 0.48$)$. The main mineralization stage characterized by local $\mathrm{U}, \mathrm{Na}, \mathrm{Pb}, \mathrm{Zn}, \mathrm{Ga}, \mathrm{Hf}, \mathrm{Sr}, \mathrm{Fe}, \mathrm{Al}, \mathrm{P}$ and $\mathrm{Zr}$ enrichments is related to the second albitization event and could probably be associated in time with the calcite-uranium stage. The identification of fault segments favorable for uranium mineralization in northern Cameroon (Poli area) is important for understanding the genesis of hydrothermal ore deposits within continental strike-slip faults and therefore has great implications for exploration strategies.
\end{abstract}

Keywords: Uranium; Kitongo; Granite; Albitization; Strike Slip Fault; Cameroon

\section{Introduction}

Low uranium commodity prices over many years up to the mid-2000s contributed to low expenditure on uranium exploration and dearth of discoveries of new $U$ deposits around the world. The Athabasca Basin (Canada) was one of the few regions in which major uranium discoveries were made during 1990s and early 2000s [1]. However, as the principal fuel for the world nuclear power plants, uranium has become a valuable source of energy in many countries and increasing demand from emerging econo-

"Corresponding author. mies such as China and India, and new market potentials in the Middle East have boosted the search for uranium deposits worldwide in the last five years [2]. In recent years, the world market of $U$ has been characterized by an imbalance between demand and supply and persistently depressed uranium prices. However, the future for uranium exploration and exploitation is not that pessimistic. For example, it is projected that available uranium stockpiles between the period 2006-2020 is $\sim 200 \mathrm{Kt}$, whereas the supply deficit of $U$ over the same period is $\sim 180$ $260 \mathrm{Kt}$ [3]. Therefore, in the long term, new U occurrences must be sought, explored, mapped and evaluated 
ready for production. This optimism is perhaps responsible for the renewed interest in uranium exploration especially in currently non-producing countries like Cameroon. This optimism also takes cognizance of the current outcry against nuclear energy following the Fukushima incidence in Japan but the authors hold the view that this will not, at least in the short run, derail the nuclear energy sector.

The exploration for $\mathrm{U}$ in Cameroon, which peaked in the period between 1971 and 1986 led to the discovery of two significant uranium occurrences in the country, as described in the IAEA-Uranium Deposit (UDEPO) database [4]. These include the Lolodorf occurrence (southeastern Cameroon) and the Kitongo occurrence (northern Cameroon). Previous works suggest that the Kitongo uranium occurrence is the result of structurally-controlled metasomatic replacement in syn-orogenic granitic plutons of Pan African age intruded along a deep-seated fault [4]. The ore is mainly of disseminated type and although the mineralization is envisaged to be thick, it has low grade [4]. The "cataclastic" ore type with uraninite as main ore mineral, is associated with fault zone; it constitutes the most economic ore type and has locally a considerable thickness. The vein type is subordinate with very thin veinlets $(<1$ $\mathrm{cm})$, but with higher grades $\left(>0.1 \% \mathrm{U}_{3} \mathrm{O}_{8}\right)$. The historical $\mathrm{U}_{3} \mathrm{O}_{8}$ resources at Kitongo are estimated between 10,000 and 25,000 tones at a grade of $0.1 \% \mathrm{U}_{3} \mathrm{O}_{8}$ [5]. The mineralization is also associated with different alteration processes. Any, if not most of the deposits that were discovered during previous exploration efforts are included in the expanded UDEPO database [6]. The resources for many of these deposits will however require additional exploration before they are sufficiently well defined to be reliable as future exploitation candidates. It is against this background that the present study was carried out.

The work described in this contribution was undertaken at a time of renewed interest in the Kitongo uranium occurrence for which Mega Uranium Corporation Cameroon PLC. now has exclusive exploration and reserve definition rights (see www.megauranium.com/main/? kitongololodorf). The primary objective of this study was to map in greater details the northwestern part of the Kogué batholiths to which the Kitongo uranium mineralizetion belongs and to document its lithological varieties and their corresponding geochemistry. Presently, Mega Uranium is actively engaged in diamond drilling of the $\mathrm{Ki}$ tongo prospect and such detailed maps and integrated geochemical data will hopefully assist in the broader understanding of the controls of uranium mineralization and its genesis at Kitongo.

\section{Regional Geology}

The Kitongo U occurrence that belongs to the Kogué granitic batholiths lies within the Central African Fold Belt
(CAFB) that is regarded as a mobile zone [7-10]. This is an intermediate domain between the West African Craton (WAC), the São Francisco-Congo Craton (SFCC) and enigmatic east Saharan Craton (Figure 1). The CAFB in Cameroon is bordered in the south by the Ntem complex (Congo craton) that continues across the Atlantic as the São Francisco craton in Brazil $[11,13]$. Northwards and beyond this unit the so-called "East Saharan Block" (ESB), almost entirely masked by the Chad basin, is located (Figure 1). The geology of the northern margin of the CAFB in Cameroon is known through the well exposed Poli Group that represents an early Neoproterozoic back-arc basin formed between 830 and $665 \mathrm{Ma}$ ([14-16].

The CAFB was interpreted as a zone of continent-continent collision [13,17-27] involving three major landmasses: the São Francisco-Congo Craton (SFCC), the Eastern Sahara block and the West African Craton [11] (Figure 1). It comprises two main granulitic rock suites: an Archaean generation in the forefront basement of the Oubanguides chain and a post Archaean generation likely Pan African within the inner zone of that orogeny [28].

Recent petrologic and isotopic data enable to define the following three main Pan-African geotectonic units at the northern boundary of the SFCC: the Yaounde Group (southern Cameroon), the Adamawa domain (central Cameroon) and the Poli Group (northern Cameroon) (Figure 2). The study area is located in the Poli Group (Figure 3) dominated by metavolcanic and metasedimentary rocks [14,31]. The lithostratigraphy is poorly defined because these rocks are interleaved and have been strongly deformed [31-34] although the metavolcanic unit is widely believed to alternate with metasedimentary units. The lower metasedimentary unit (Sakje unit) has been affected by medium- to high-grade metamorphism [32,34], while the upper unit underwent low grade metamorphism. However in some localities, transition from the low grade upper sedimentary unit to the Sakjé unit is gradational as at "Buffle Noir" and in western Poli (Figure 3) [33,35]. In both regions, the upper and lower metasediments show comparable greywacke composition [14,35]. The metasedimentary unit on a wider scale is composed of either purely volcanogenic clastic rocks (mainly tuffs) or variably reworked clastic rocks (metagreywackes). Conglomerate layers are frequently observed in most of the sedimentary sequences. The metavolcanic unit includes rhyolite and tholeiitic basalts. The tectonics of the Poli region is marked by E-W antiform and synform characterizing gentle folding of a regional flat-lying foliation probably formed during an early thrust evolution. Many generations of wrench zones in that area crosscut those early folds and foliation related to the thrusting and nappe refolding. These include the left and right wrench movements: the D2 and D3 Pan-African phases involving major sinistral and dextral SZ that have almost operated at right angle. The left 


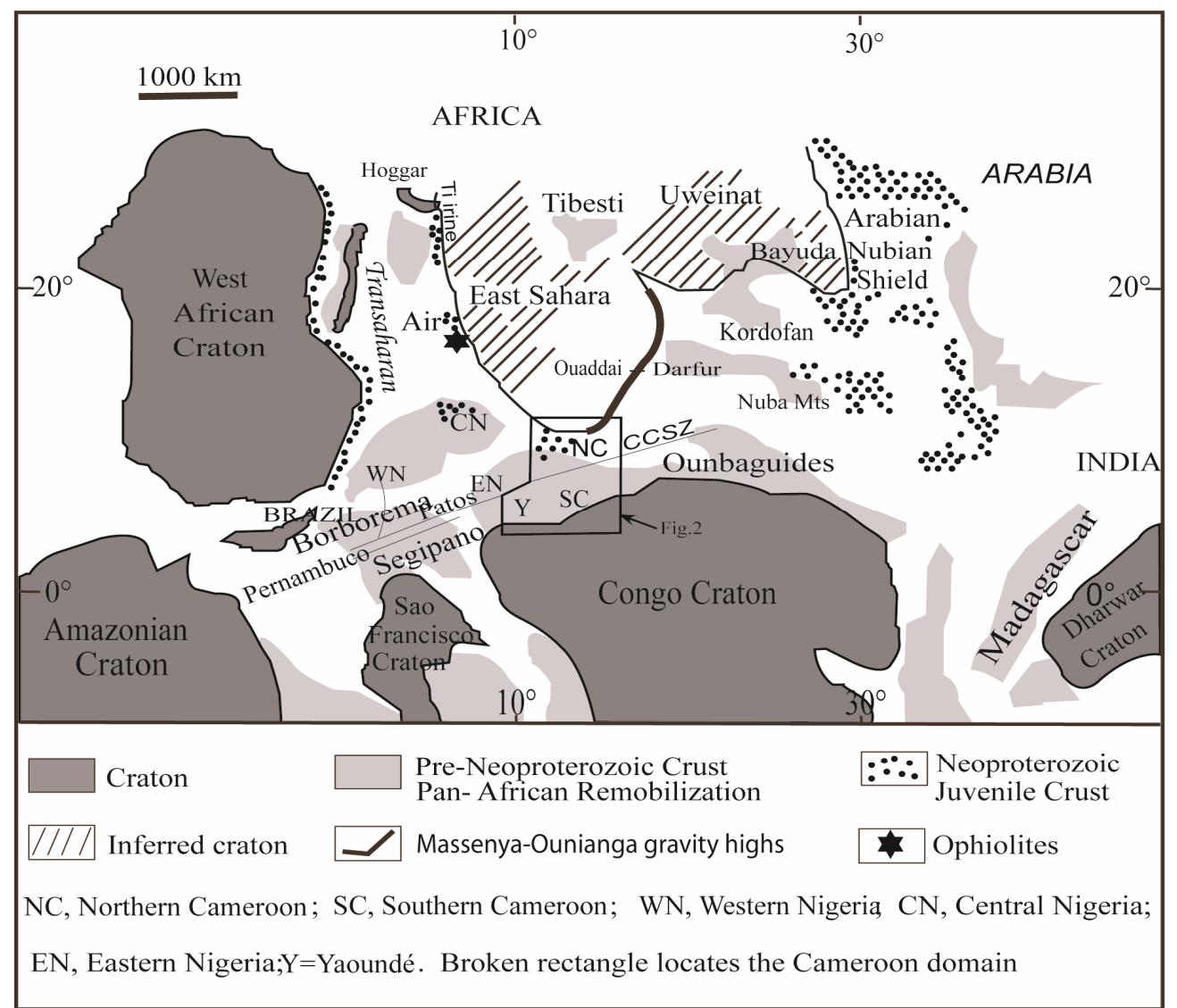

Figure 1. Geological sketch map of Central-North Africa (western Gondwana), and location of Cameroon [11] modified from [12].

wrench movement (ca 613 - $585 \mathrm{Ma}$ ) is represented by the major Balché (BSZ) and "Buffle Noir"-Mayo Baléo shear zones (BNMB) and the synthetic shear zones represented by the Godé-Gormaya (GGSZ) and Mayo Nolti shear zones (MNSZ); the right wrench movement younger in age (ca 585 - $540 \mathrm{Ma}$ ) than the left one is represented by the "Vallée des Roniers" shear zone (VRSZ) and Demsa shear zone (DSZ) coeval with down-slip movements parallel to the Godé and Gormaya segments [11]. Granitic intrusions, mainly of Pan-African age, are widespread in the Poli Group (Figures 2 and 3). A Rb-Sr age of ca 590 $\pm 16 \mathrm{Ma}$ on biotite from these rocks [9] can be approximated to the emplacement age of the massif. The emplacement of post-collisional granitoids was controlled by strike slip faults. The metamorphism is of medium- to high-pressure type and localized anatexis resulted in the genesis of migmatites. The associated plutonism evolved from calc-alkaline to alkaline compositions $[21,36]$.

\section{Local Geology}

\subsection{Lithology}

The U occurrence mapped in this study (Figures 3 and 4) referred to as the Kitongo Uranium occurrence is located at the northwestern margin of the Kogué granitic batholiths (note that the northwestern margin of the Kogué granitic batholiths shall also be referred to as the Kitongo granite). It covers an area of $\sim 2.34 \mathrm{~km}^{2}$, i.e. $\sim 1.8 \mathrm{~km}$ in length and $\sim 1.3 \mathrm{~km}$ in width. Detailed geological data from the area under study are scarce and are mainly reconnaissance reports. This area consists of a horst-like structure with many cliff-faces amongst which the Kitongo cliff-face is the most important in extension (averagely $250 \mathrm{~m}$ of escarpment); it is where galleries were dug. This cliff-face corresponds to the Kitongo shear zone trace in 2 dimensional view (Figure 4). Thick overburden made up of huge number of boulders of various sizes exhibiting a chaotic aspect hampers observations. However the continuous aspect of outcrops has enabled mapping from which four main rock types were distinguished hereafter referred to as: the metavolcanic and metasedimentary unit, the fault rocks unit, the granodioritic unit and the granitic unit. Mafic dikes were also mapped but are relatively less important.

\subsubsection{Metasedimentary and Metavolcanic Unit}

These rocks belong to the Poli Group and they outcrop at the northwest of the Kitongo granite. This unit is essen- 
tially made up of interleaved dark grey basic meta-volcanic and light grey meta-sedimentary rocks and amphibolebearing schist with a strong N045-078E-trending regional foliation. This unit is crosscut by many faults and fractures of various strike and dip. In certain areas, quartzo-feldspathic lenses display boudinage subparallel to the general foliation. S-C fabrics associated with the early sinistral and late dextral movements are widespread as well as microfolds with crenulation cleavages.

\subsubsection{Fault Rocks}

The fault rocks outcrop between the Kitongo granite and the granodiorite and at some locations they distinctly separate the Kitongo hornblende biotite granite from the Poli Group sensu strictu (Figure 4). The fault rocks are characterized by the interpenetration of Poli Group rocks and granite exhibiting a trellis aspect defining a sinistral shear zone $\sim 70 \mathrm{~m}$ wide within which a well developed mylonitic foliation (N050-N080E, 70SE to vertical) is

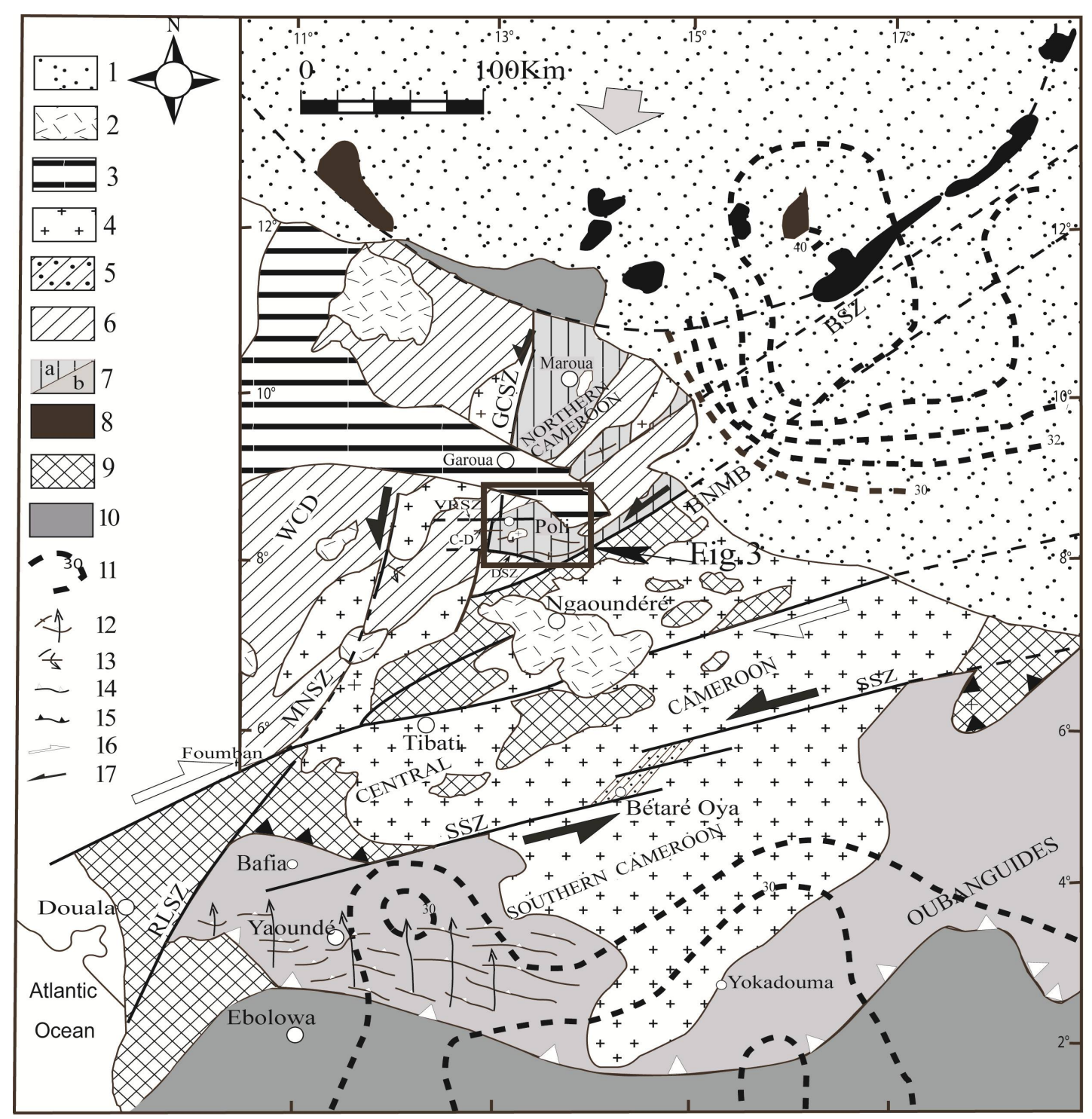

Figure 2. Structural map of the eastern province (coastal region, [11] modified from [29] see location box in Figure 1). 1: Quaternary sediments; 2: Neogen volcanics; 3: Mesozoic sediments (Benue Trough); 4: Late syntectonic subalkaline granitoids; 5: Lom syntectonic basin (meta-sediments, conglomerates, volcanic ashes and lavas); 6: Western Cameroon Domain (WCD; early syntectonic basic to intermediate calc-alkaline intrusions, 660 - $600 \mathrm{Ma}$ ); 7a: Poli Group (active margin Neoproterozoic supracrustal and juvenile intrusions) 7b: Yaoundé Group (intracratonic deposits); 8: Massenya-Ounianga gravity highs (10 - 30 mGal); 9: Adamawa-Yadé and Nyong Paleoproterozoic remnants; 10: Craton and inferred craton; 11: Effective elastic thickness curves (km), [30] ;12 - 17 = Structural elements: 12: Foliation and lineation trends; 13: upright and overturned antiforms; 14: Main frontal thrust zone (exhumation); 15: Main thrust zone likely associated to crust redoubling zone; 16: Right lateral sense of wrench movement; 17: Left lateral sense of wrench movement. Large grey arrow represents regional mainstress direction controlling crust thickening and sinistral wrench movement, respectively. 


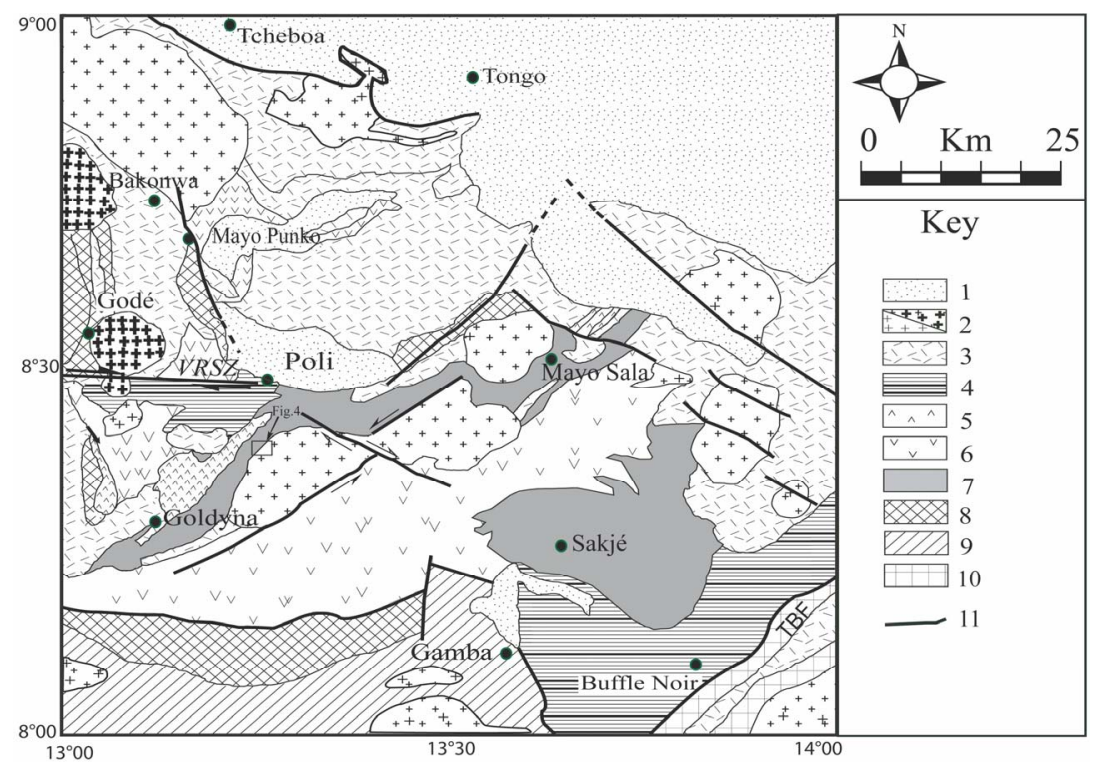

Figure 3. Geological map of the Poli region, modified from [16]. (1) Post Pan-African cover; (2) Post tectonic Godé type granitoids/Syn-to-tardi tectonic Kogué type granitoids (Hbl-Bt granites); (3) Hbl-Bt \pm Grt Pan-African orthogneisses; (4) Ms-Chl schists; (5) Goldyna metarhyolites; (6) Ep-Chl Metabasalts; (7) Bt-Ms \pm Grt-St-Ky Micaschistes; (8) Bt and Bt-Hbl gneisses; (9) Undifferentiated gneisses intercalating with bands of Grt-Ky-Bt metapelites; (10) Mylonitic gneisses associated with Grt-Cpx-Opx-PI bearing granulitic metabasites; (11) Stike-slip fault; TBF represents the Tcholliré-Banyo Fault which is the limit between the Adamawa-Yadé Domain and the north-western Domain.

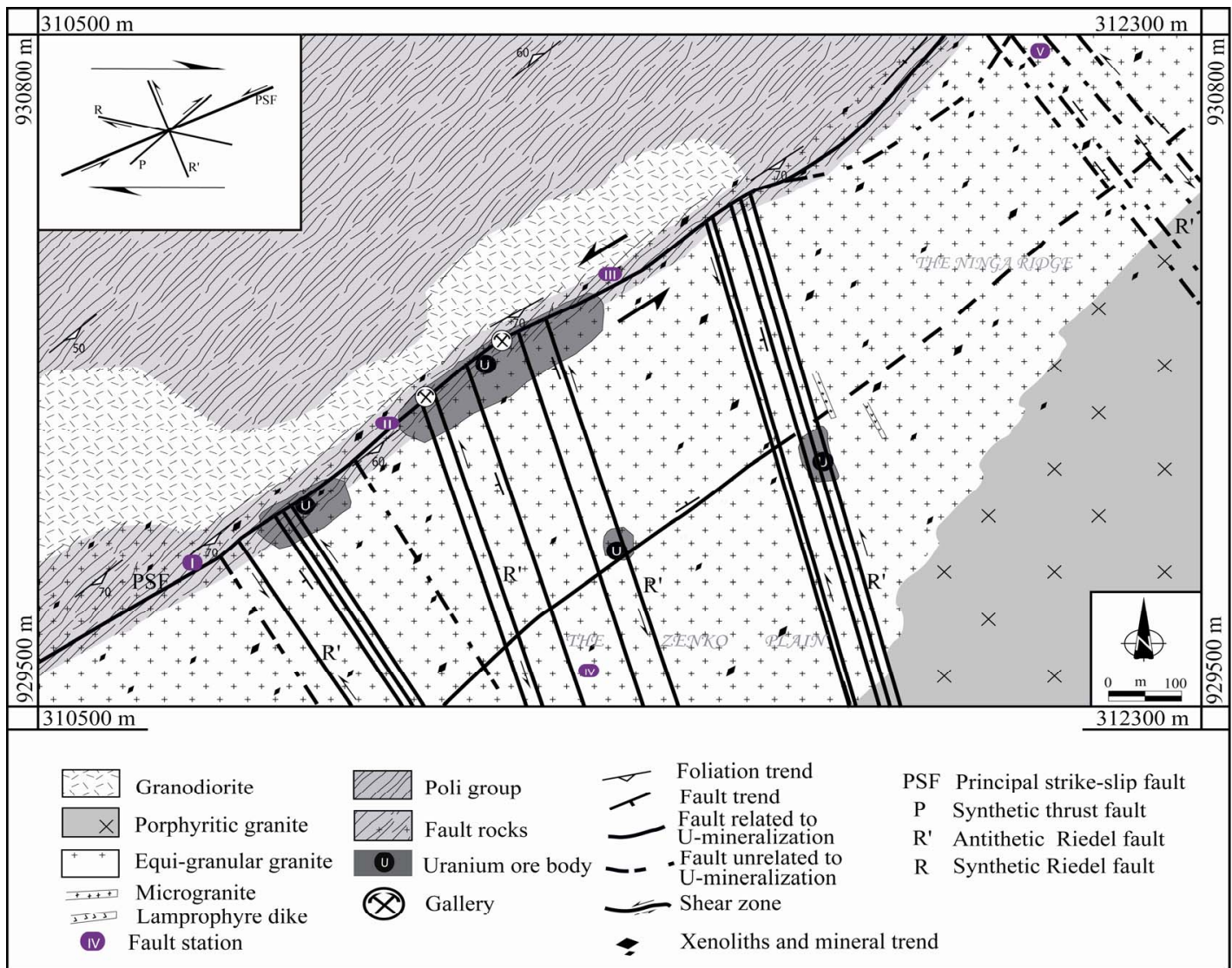

Figure 4. Geological map of the Kitongo Uranium deposit, which is structurally dominated by early ductile PSF ENE-WSW trending fault and late overprinting brittle conjugate ( $R$ ') faults. Intersections between ENE-WSW trending faults and $R^{\prime}$ faults are the most important sites for uranium. The terminology PSF is from [37]. 
discernable (Figures 4 and 6). Both the granitic rocks and metasediments/metavolcanics are affected with no evidence of localized partial melting (Figures 5(a)-(b) and Figure 7).

\subsubsection{Granodionitic Unit}

This rock outcrops at the NW of the Kitongo granite and it is separated from the latter by the fault rocks (Figure 4). The rock is greenish and crosscut by aplitic veins. Two generations of granodiorite were distinguished; the older granodiorite outcropping as large inclusions within the younger one. The average orientation of the long axes of these inclusions as well as the mineral lineation in these plutons are N70-80E. Microstructures within this
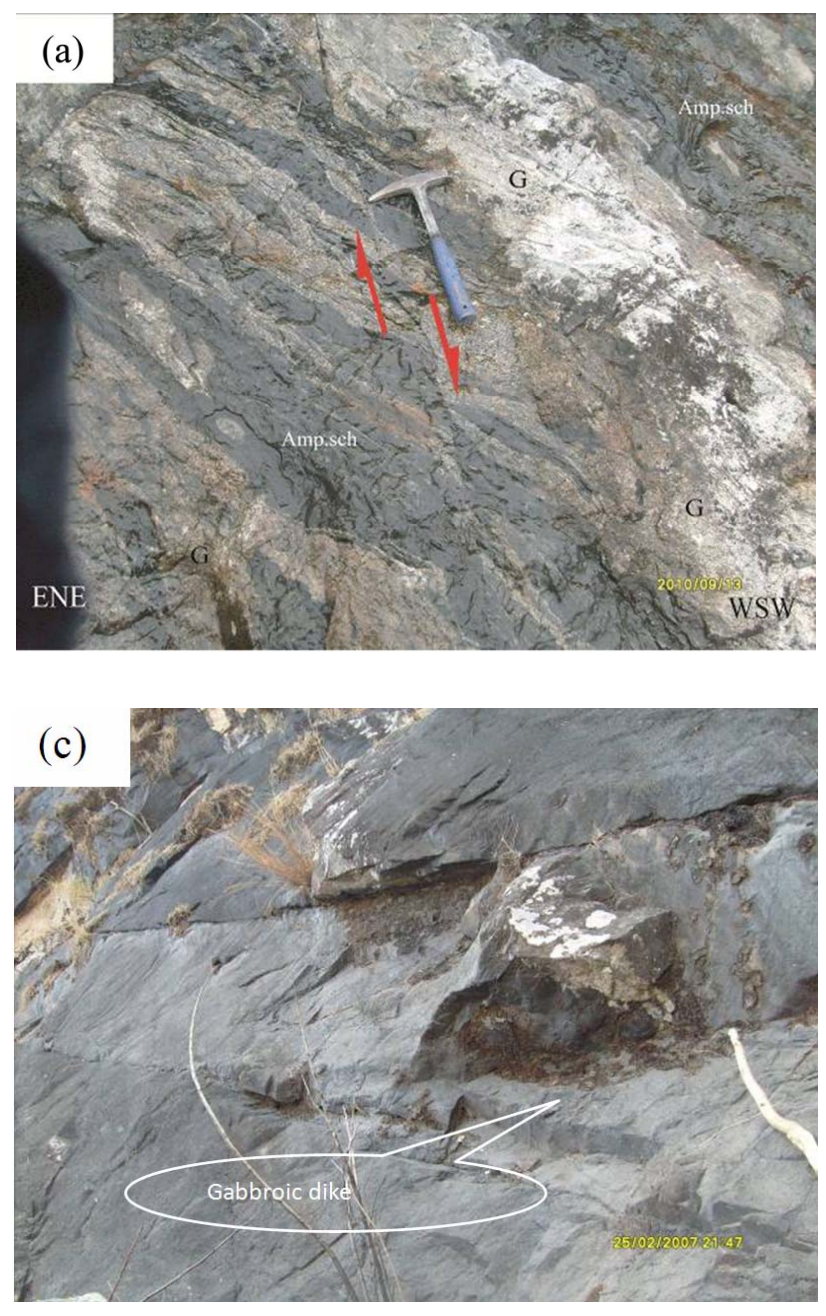

granodiorite include a stretching lineation as well as micro S-C fabric in the groundmass. These features are reminiscent of microshearing with $\mathrm{mm}-\mathrm{cm}$ relative displacements. Three fault sets are recognisable in this unit, namely from the oldest to the youngest, the N022E90, N122E90 and N058E90 vertical fault trends. Small ptygmatic folds are also present. In hand specimen, the following mineral assemblage is observed: amphibole, plagioclase, quartz, and biotite and minor muscovite and K-feldspar.

\subsubsection{Granitic Unit}

In the study area three granitic facies were mapped. These are the porphyritic hornblende-biotite granite, the equigranular hornblende-biotite granite and the microgranite.
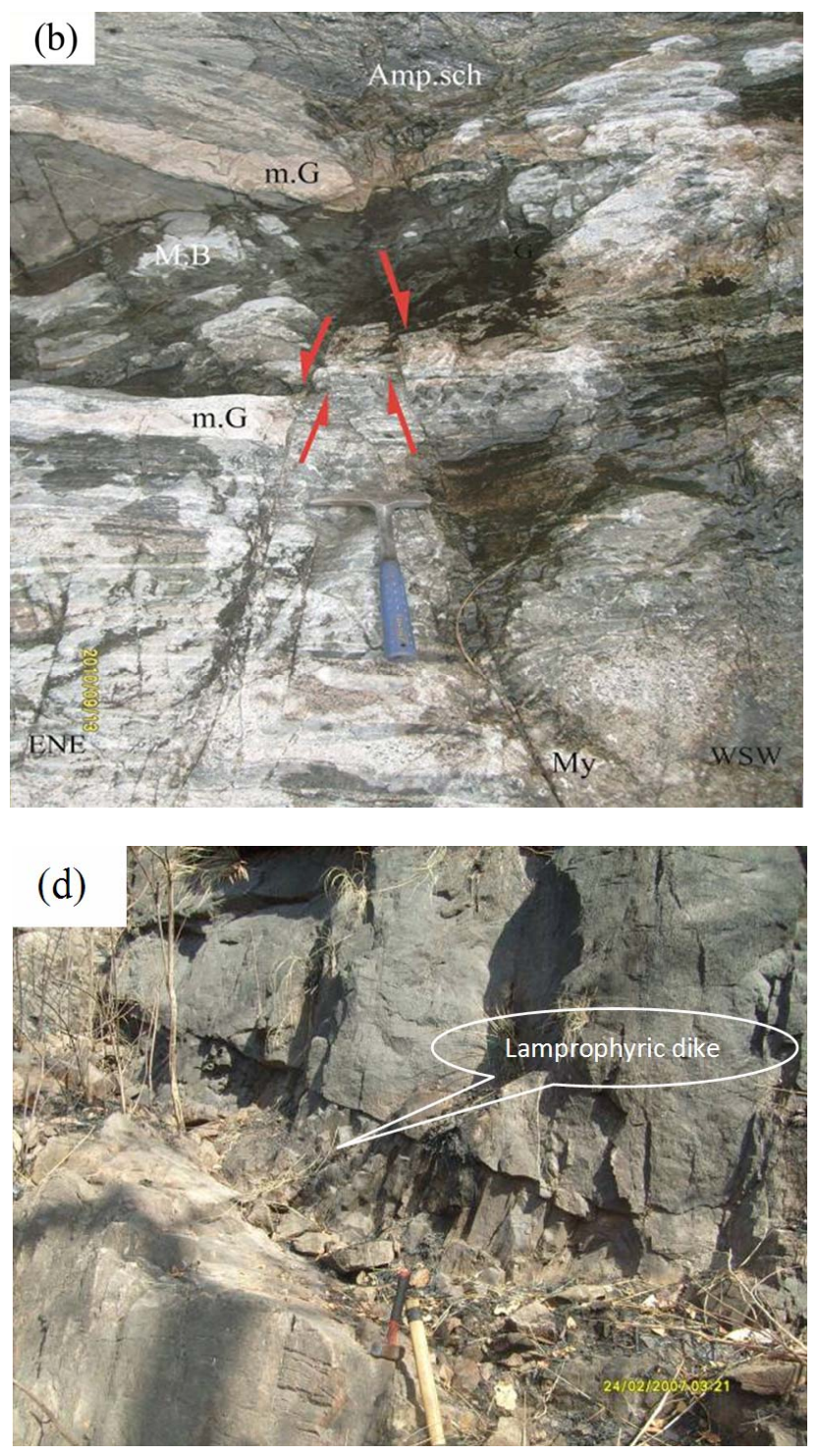

Figure 5. Lithologic features of the Kitongo granite (vertical views). (a) and (b) The trellis aspect of the fault rocks evidencing the penetration of granite within the amphiboloschist-Poli Group: Amph.sch = amphibloschist, $\mathrm{My}=$ mylonites, $\mathrm{G}=$ granite, m.G = micro-granite, M.B = metabasalt; normal fault markers are sub-vertical components of R' fault system; (c) Gabbroic dike; (d) Lamprophyric dike on the Kitongo cliff-face. 

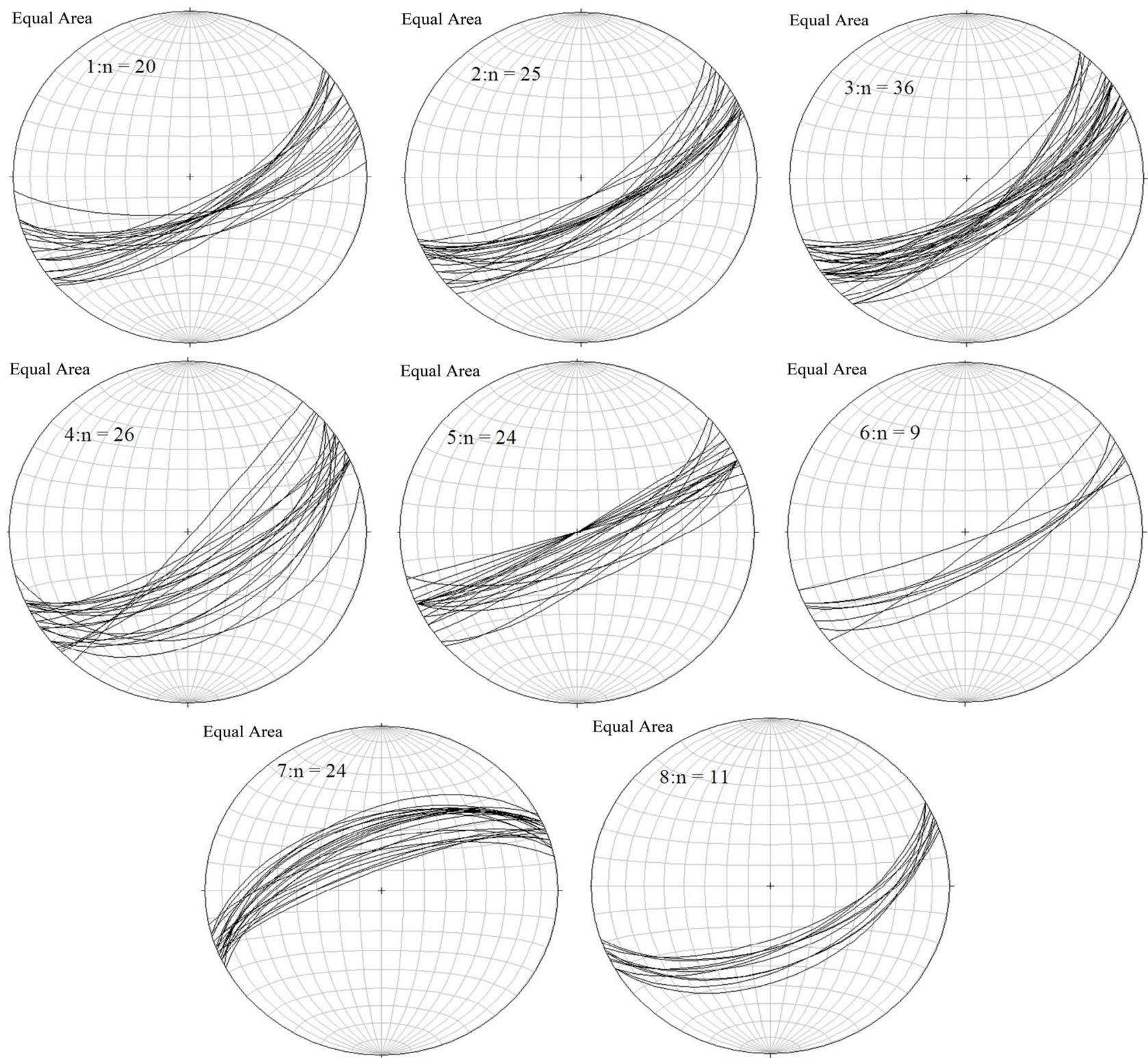

Figure 6. Equal area lower hemisphere stereonet projection of foliation planes within fault rocks (1, 2, 3, 4, 5 and 7) and Poli Group (s.s.) (6 \& 8) averagely N70 trending direction.

The porphyritic amphibole-biotite granite is a light coloured rock characterized by the dominance of euhedral K-feldspar phenocrysts ( 2 - $3 \mathrm{~cm}$ long), plagioclase feldspar and quartz within a biotite-amphibole dominated groundmass. The transition from this granite to the equigranular amphibole-biotite granite is gradational and it is marked by the steady decline in K-feldspar phenocrysts to medium grain size ( $4 \mathrm{~mm})$ and the incipient appearance of plastic deformation of the Kitongo granite towards its borders. These gradational processes are linked to magmatic and tectonic events interacting at large scale. The equigranular amphibole-biotite granite has both plagioclase and alkali feldspar and it is restricted to the $\mathrm{Ki}$ tongo granite's margin. The rock is medium-grained ( $\sim 4$ $\mathrm{mm}$ ) although aggregates of phenocrysts of K-feldspar are locally observed. Quartz grains are irregular to elongated and together with the alignment of amphibole and biotite these mineral phases define a strong mineral lineation and foliation. Accessory minerals in this granite facies include chlorite and/or epidote, aegirine/riebeckite and disseminated sulphides. The equigranular amphibole-biotite granite exhibits clear petrographic evidence of substantial post-magmatic recrystallization accompanied by a two-stage albitization occurring in successive steps. These albitization events are continuous in time and spatially bound to one another through fuzzy transitions. The first phase of albitization with weak degree was identifiable but in the xenoliths zone and in the porphyritic granite. 

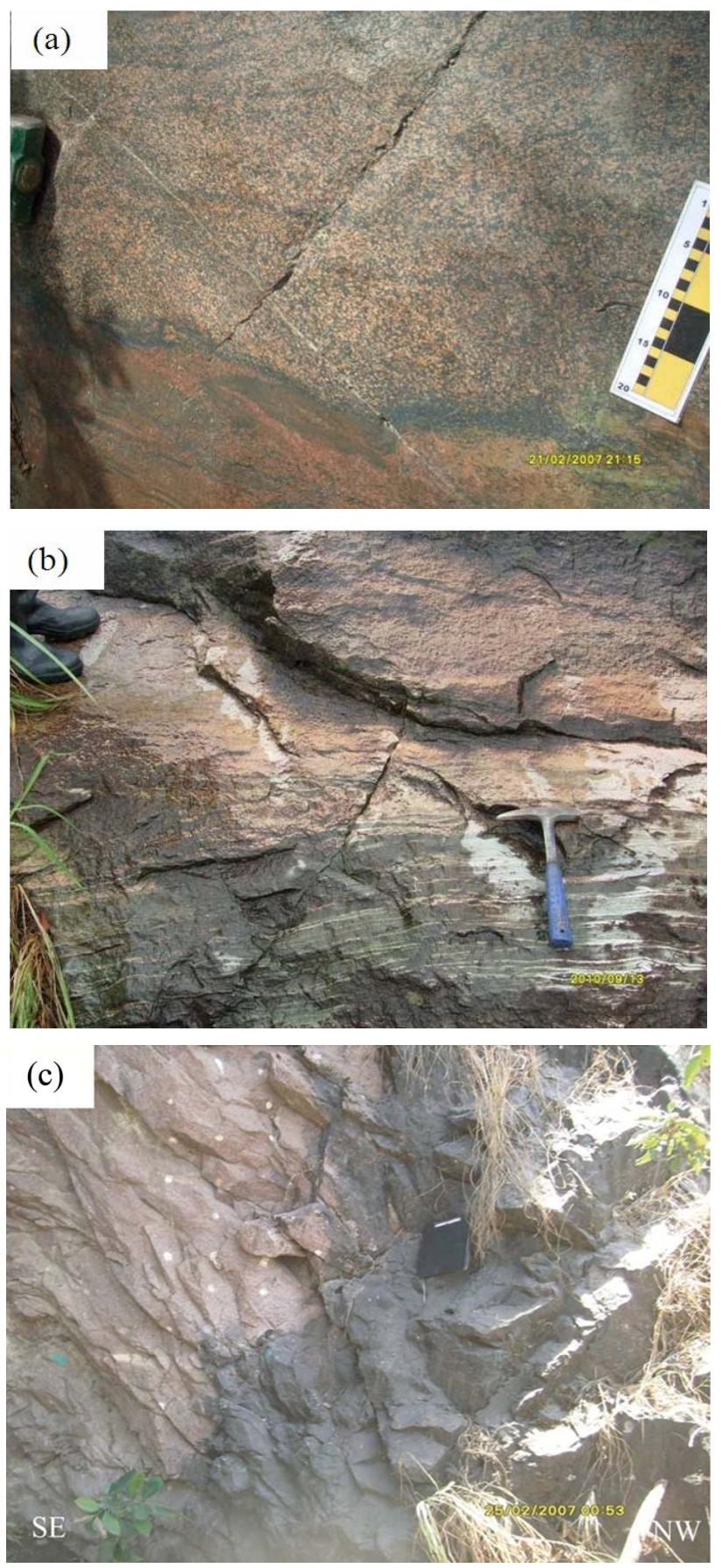

Figure 7. Lithologic features on the Kitongo SZ. (a) Protomylonite; (b) Ultramylonites, notice the gradational contact between the granite and amphiboloschist (horizontal view); (c) Breccias occurring in both granite and fault rocks (vertical view).

The second albitization event was more intense and overprinted the first. This was only effective around fault intersections along the Kitongo shear zone and to a lesser extent on the Zenko plain, where the central (core) zone is surrounded by alternation of variably altered granites outwards exhibiting lithologic zoning. It is characterized by the increase in albite, while quartz and alkali feldspar decrease without extensive textural changes. Indeed where this hydrothermal alteration phase is very strong, albitite facies develop. With respect to the degree of albitization and quartz contents, four sub-facies of the equigranular granite were distinguished. These facies, from the periphery towards the centre are as follows: the relics of the original equigranular granite; albitized granite; quartz albitite/episyenite and albitite sub-facies. The albitized granite sub-facies reflect the existence of hydrothermal alteration gradient intensity across the granite. Residual quartz and plagioclase also exist as well as rare sulphide grains. In addition, transgranular fractures in this sub-facies are filled in by chlorite and/or epidote. The quartz albitite/episyenite sub-facies is typified by the total disappearance of alkali feldspar but few quartz grains can still be observed. The mineralogy is chiefly composed of albite, hornblende, aegirine, and accessory biotite, chlorite and/or epidote. The albitite sub-facies is characterized by the total replacement of alkali feldspar by albite. Here albite is either uniformly distributed in the rock or forms euhedral crystals filling the quartz dissolution cavities, or it forms stringers within the intensively mylonitized bands along the Kitongo shear zone. Albitites are red in colour; quartz is totally absent although silicification is often recognized in association with secondary calcite along microcracks; the mineralogy comprises albite, aegirine and hornblende, chlorite and/or epidote. The microgranite is mainly found on the Zenko plain as $0-2 \mathrm{~m}$ thick veins and trending N160E (Figure 4). However, this rock facies is also found within the fault rocks area (Figures 5(a) and (b)). The mineralogy includes quartz, K-feldspar and sparse biotite and amphibole.

\subsubsection{Mafic Dikes}

A series of N-S-trending gabbroic and lamprophyric dikes cutting across the granite intrusions are clearly observed on the Kitongo cliff face. Gabbroic dikes are melanocratic and massive and very hard and are characterized by inequigranular assemblage made up of fine grains of pyroxene, hornblende and phenocrysts of plagioclase (Figure 5(a)). The lamprophyric dikes also occur on the Zenko plain where they are only a few meters thick and trending N160 (Figure 4). On the cliff face these dikes dip at $40^{\circ}$ to $50^{\circ} \mathrm{SW}$ and vary between 0.7 to $1.8 \mathrm{~m}$ in width (Figure 5(b)). These dikes are greyish in colour, dense and fine-grained. The mineral assemblage includes very fine grains of biotite, hornblende and pyroxene.

\subsection{Fault Zone Architecture of the Kitongo $U$ Occurrence}

The fault zone is the single most important feature in the Kitongo area related to the $U$ concentration. It is therefore treated here in greater details. The fault zone at the 
Kitongo U occurrence includes the Kitongo SZ characterized by ductile and plastic deformations, and the conjugate fault system made up of brittle structures overprinting the SZ.

\subsubsection{The Kitongo SZ}

The Kitongo granite margin at the studied locality is outlined by the Kitongo shear zone (PSF) well exposed along the fault rocks. The studied section of the shear zone measures about $1.6 \mathrm{~km}$ in length and its trend varies between NE to ENE (Figure 4). This is a sinistral shear zone with two different textures including mylonites and breccias. The mylonitic fault rock that shows relatively sharp contacts with the granite includes both protomylonites (Figure 7(a)) and ultramylonites facies (Figures 7(b) and (c)) are commonly associated to stylolites. The plastic deformation at Kitongo includes pervasive mineral lineation and linear fabrics defined by xenoliths within the granitoid. At outcrop scale the mineral lineation has the following attitude: N050-070E, $\geq 65^{\circ} \mathrm{SE}$ (Figure 8(a)). This

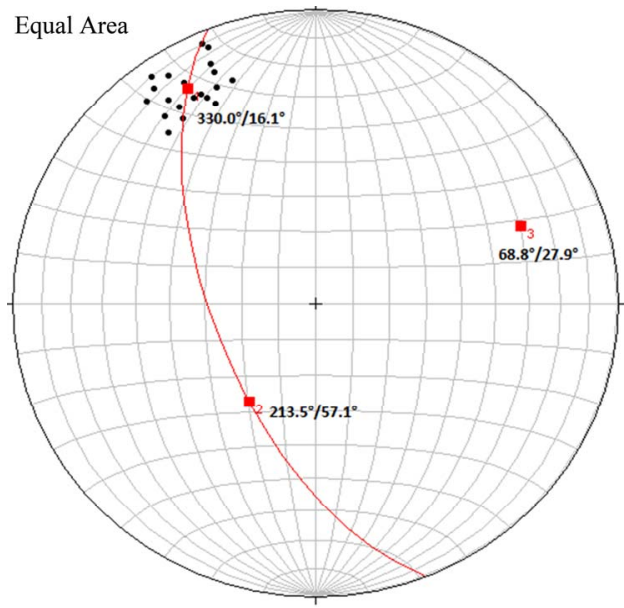

(a)

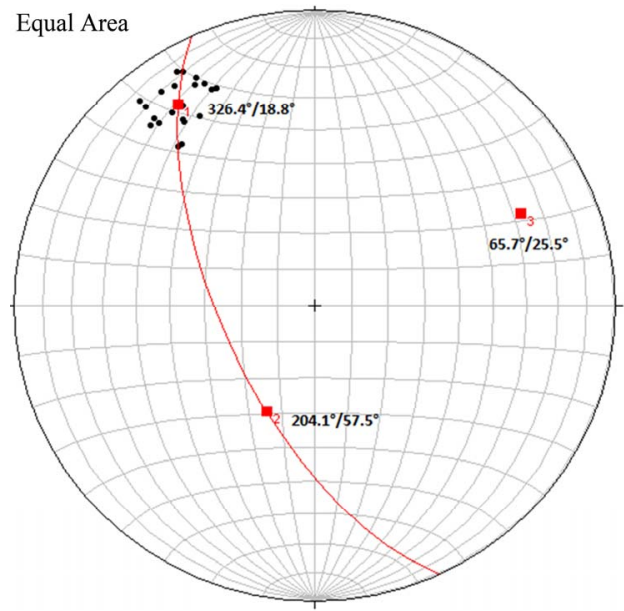

(b)

Figure 8. Equal area lower hemisphere stereoplots of (a) mineral lineation; (b) Xenoliths trend. trend is sub-parallel to the general orientation of the $\mathrm{Ki}$ tongo SZ. Abundant xenoliths predominantly grey in colour were observed at the study section of the Kitongo granite. They are mostly lensoid in shape and range from millimetre to $1.5 \mathrm{~m}$ in size and their modal compositions generally correspond to micro-granodiorite. They are common in the equigranular granite (Figure 9(a)) and within the fault rocks (Figures 9(b) and (c)). The xenoliths alignment defines a fabric that trends N050-066E, $\geq 65^{\circ} \mathrm{SE}$ (Figure 8(b)).
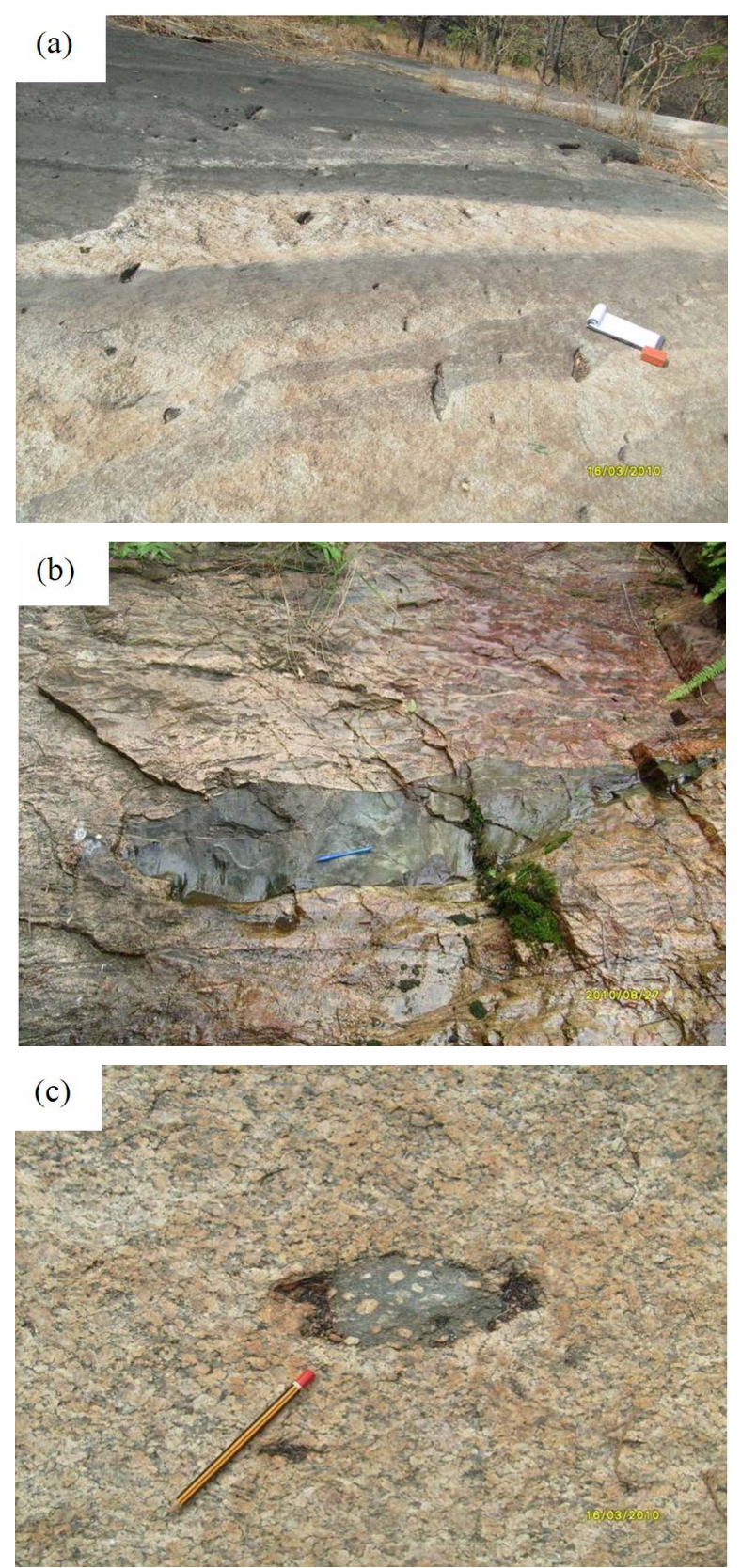

Figure 9. Xenoliths on outcrop: (a) Densely packed xenoliths within equigranular granite; (b) Mega xenoliths within the fault rocks; (c) Micro-granodioritic xenoliths containing porphyritic alkali feldspar (horizontal view). 


\subsubsection{The Conjugate Fault System}

Numerous near-parallel closely spaced and steeply dipping normal faults ( $R$ ' fault) and fractures developed at high but variable angles to the PSF (Figures 4 and 10) extend into the surrounding granitoid, configuring it into numerous triangular to irregular blocks (Figure 4). The sub-vertical component of these conjugate faults and fractures represented on Figure 4 were recorded in fault rocks (Figures 5(a) and (b)). This conjugate faults system corresponds to a younger tectonic event overprinting the PSF. Breccias occur locally in granite and mylonites as a result of the intersection of these conjugate faults with the PSF (Figure 7(c)). Based on the bisectors between the Kitongo SZ and these R' faults, seven fault orientations were discerned including: the NE-SW-trending $\left(35^{\circ}-53^{\circ}\right)$ coplanar and steeply dipping $\left(70^{\circ}-85^{\circ} \mathrm{NW}\right.$ to vertical $)$, the ENE-WSW-trending $\left(58^{\circ}-70^{\circ}\right)$ steeply dipping to vertical, the E-W-trending $\left(85^{\circ}-98^{\circ}\right)$ steeply dipping $\left(72^{\circ}\right.$ $80^{\circ} \mathrm{S}$ to vertical), the ESE-WNW-trending $\left(105^{\circ}-120^{\circ}\right)$ steeply dipping $\left(64^{\circ}-85^{\circ} \mathrm{SW}\right.$ to vertical), the SE-NWtrending $\left(126^{\circ}-145^{\circ}\right)$ coplanar and steeply $\left(68^{\circ}-84^{\circ} \mathrm{SW}\right.$ to vertical $)$, the SSE-NNW-trending $\left(148^{\circ}-167^{\circ}\right)$ coplanar steeply dipping $\left(67^{\circ}-88^{\circ} \mathrm{WSW}\right.$, ENE to vertical) structures and the N-S-trending $(010,170$ - 177) coplanar steeply dipping $\left(58^{\circ}-88^{\circ} \mathrm{E}\right.$ or $\mathrm{W}$ to vertical) structures. The ENE-WSW faults system comprises two parallel faults including the Kitongo SZ (PSF fault) that trends $\mathrm{N} 050^{\circ}-080^{\circ}$, 70SE (Figure 4). These features together with the late mafic dikes (Figures 5 (c) and (d)) suggest extensional deformation and the extension direction inferred from stereonet plots of the conjugate faults is parallel to the Kitongo SZ (WSW- ENE) (see Figure 11).

\section{Radioactivity}

Thick overburden at Kitongo masking the most important part of the mineralized zones has complicated surface radiometric patterns. Additionally, it has not been possible to investigate over the Kitongo cliff-face due to its vertical slope. However radiometric prospection using a hand held scintillometer over the study area enabled the identification of four U-anomalies aligned in the same trend. This spotted mineralization occurred at fault intersections of the ENE-WSW-trending faults and the overprinting Riedel fault system. The country rock is the hornblende-biotite equigranular granite that has experienced various forms of alteration at these intersections notably mylonitization along the Kitongo SZ, albitization, haematitization, silica dissolution, chloritization and uranium mineralization. The intensity of the alteration decreases away from the intersections that served as pathways for the hydrothermal fluids. This spatial distribution of mineralization at fault intersections therefore reflects an essential relationship between fault movement, mineralizeing fluids and subsequent U-ore deposition. Very high radiometric values, up to $3500 \mathrm{cps}$ (count per second) were recorded in the red albitites from fault intersections, while red albitites along the PSF, away from fault intersections showed only background values as well as the equigranular granite weakly altered during the first phase albitization alone. Uranium mineralization is clearly hosted in aureoles of hydrothermally-altered rocks and was controlled by the intersections of perpendicular to sub-perpendicular fault sets to the ENEWSW-trending faults. Additionally, the highest uranium content, of the order of $0.22 \% \mathrm{U}_{3} \mathrm{O}_{8}$ was recorded along the Kitongo SZ at its intersection with the N160E faults ( $R$ ' fault), where red albitites pervade the fault rocks thus, this intersection is actually the main U-ore hosting structure (Figure 4).

\section{Whole Rock Geochemistry}

Samples used in this study were exclusively collected from outcrops. Whole rock geochemistry was performed at Alex Steward Laboratory Group (OMAC) in Ireland after a sample preparation consisting of crushing and pulverizing at OMAC Cameroon. The samples were fused with lithium metaborate and lithium tetraborate at $1000^{\circ} \mathrm{C}$ in a graphite crucible furnace. Processed samples were then dissolved in dilute $\mathrm{HNO}_{3}$ and analyzed by ICP-AES for major elements. The same solution was analyzed by ICP-MS for a suite of elements consisting of trace elements including REE. The major, trace and REE data for the representative rock samples from the study area are given in Table 1.

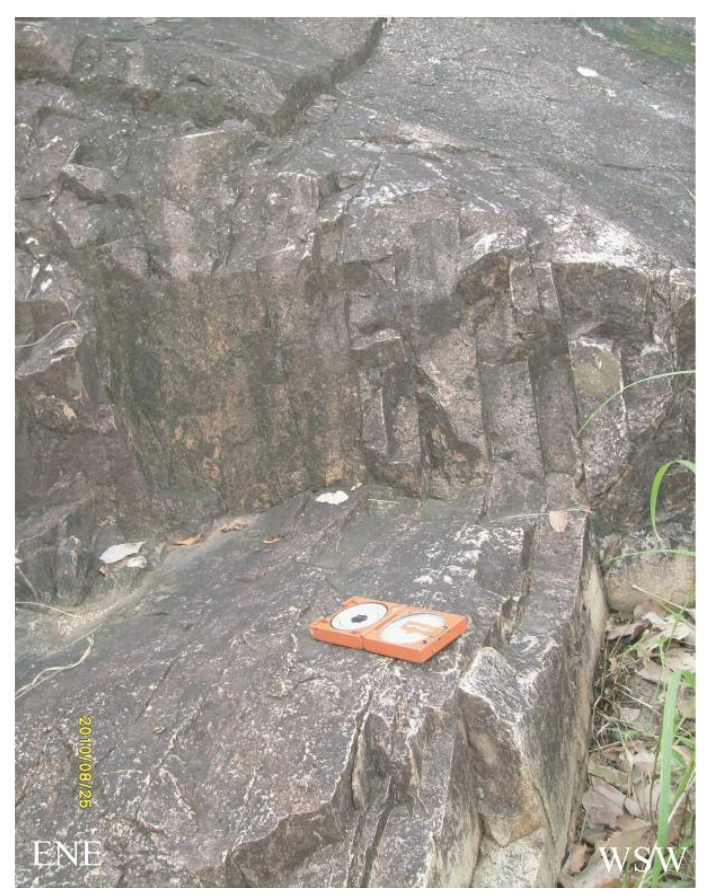

Figure 10. Illustration of closely spaced and steeply dipping normal R' faults overprinting the Kitongo SZ (horizontal view). 


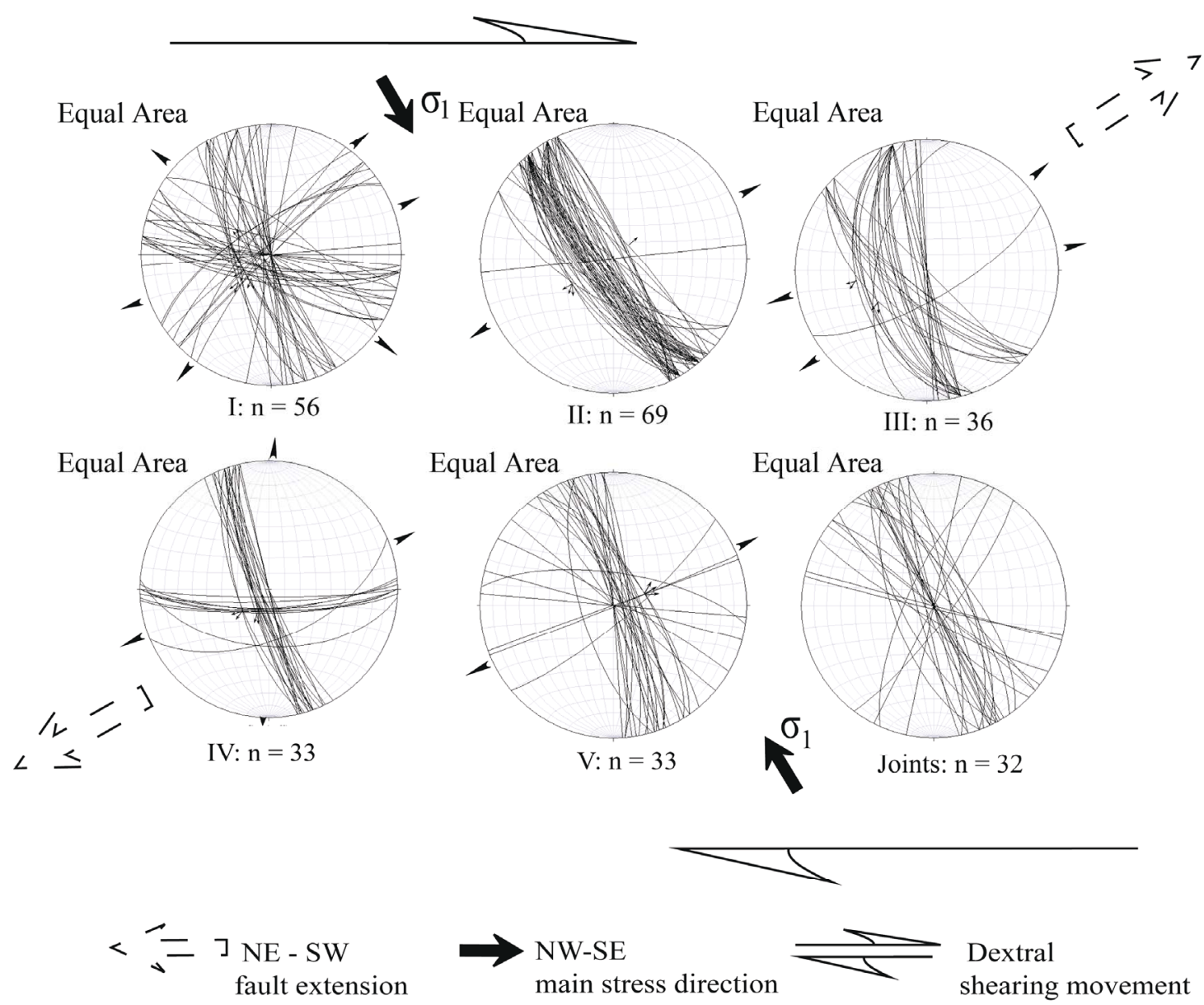

Figure 11. Equal area lower hemisphere stereonet projection of fault planes at the sites of measurement $\mathrm{I}$ to $\mathrm{V}$ and joints; these faults correspond to the $R$ ' faults system overprinting the Kitongo. Large black arrows = direction of extention, small arrows indicate the "slicken side sense" of the movement. Note the NE-SW extension and the associated NW-SE main stress direction inferred from the Riedel fault model.

\subsection{Major Elements}

The equigranular and porphyritic granite have 62.89 $70.91 \mathrm{wt} \% \mathrm{SiO}_{2}$ and $\mathrm{Al}_{2} \mathrm{O}_{3}$ values that range from 13.16 $18.59 \mathrm{wt} \%$. Their $\mathrm{MgO}$ content is low, $0.02-1.03 \mathrm{wt} \%$ as well as $\mathrm{CaO}(0.24-1.88 \mathrm{wt} \%)$ and $\mathrm{K}_{2} \mathrm{O}(0.08-5.32$ wt $\%$ ) while they have higher $\mathrm{Na}_{2} \mathrm{O}$ content (4.33 - 10.92 $\mathrm{wt} \%)$. The fault rocks have variable composition with wide variation in major element abundances (57.74 $70.86 \mathrm{wt} \% \mathrm{SiO}_{2}, 14.63-18.06 \mathrm{wt} \% \mathrm{Al}_{2} \mathrm{O}_{3}, 1.46-3.70$ wt $\% \mathrm{CaO}, 5.58-9.75 \mathrm{wt} \% \mathrm{Na}_{2} \mathrm{O}, 0.50-2.81 \mathrm{wt} \% \mathrm{~K}_{2} \mathrm{O}$, $0.93-1.07 \mathrm{wt} \% \mathrm{MgO}, 4.52-4.99 \mathrm{wt}^{\mathrm{t}} \% \mathrm{FeO}^{\mathrm{t}}$ ) reflecting geochemical redistribution of elements during fluid circulation within the shear zone. The geochemical classification of the rock units in the Kitongo area is shown on the total alkali-silica (TAS) diagram [38] (Figure 12(a)). Rock samples from the Kitongo $U$ deposit fall in granite (s.s.) and syenite fields in TAS diagram (Figure 12(a)). On the basis of the classification scheme [39] (Figure 12(b)) rock specimens of the Kitongo $U$ occurence show wide distribution from tholeiite to shoshonite series. As a whole, the wide distribution of rock types on the $\mathrm{K}_{2} \mathrm{O}$ vs. $\mathrm{SiO}_{2}$ diagram (Figure 12(b)) is consistent with the degree of hydrothermal alteration characterized by the depletion in $\mathrm{K}_{2} \mathrm{O}$. A definite calc-alkaline differentiation trend is indicated by all the samples on the $\mathrm{Na}_{2} \mathrm{O}+\mathrm{K}_{2} \mathrm{O}-\mathrm{FeO}^{\mathrm{t}}$ - $\mathrm{MgO}$ (AFM) ternary plot (Figure 12(c)). The $\mathrm{Al}_{2} \mathrm{O}_{3} /$ $\left(\mathrm{CaO}+\mathrm{Na}_{2} \mathrm{O}+\mathrm{K}_{2} \mathrm{O}\right)$ versus $\mathrm{Al}_{2} \mathrm{O}_{3} /\left(\mathrm{Na}_{2} \mathrm{O}+\mathrm{K}_{2} \mathrm{O}\right)[\mathrm{A} /$ CNK vs. A/NK] diagram [42] (Figure 12(d)), shows clustering close to the dividing lines between metaluminous and peralkaline fields but the metaluminous nature of the granitoids is further substantiated by the presence of calcic phases such as hornblende.

On the Harker binary diagrams, granitoids and their fault rock derivatives form mixed clusters (Figure 13). An overall decreasing trend of $\mathrm{CaO}, \mathrm{FeO}^{\mathrm{t}}$, and $\mathrm{MgO}$ with progressive increase of $\mathrm{SiO}_{2}$ signifies the early crystallization of mafic minerals, while the downward trend of $\mathrm{Al}_{2} \mathrm{O}_{3}$ is consistent with feldspar crystallization. $\mathrm{K}_{2} \mathrm{O}$ and $\mathrm{Na}_{2} \mathrm{O}$ exhibit sympathetic relationship with $\mathrm{SiO}_{2}$ which is in accordance with the empirical law of differentiation where orthoclase is enriched in late phase differentiation. 
Hence, a moderate to strong magmatic fractionation is inferred.

On the geotectonic discrimination diagram based on multicationic R1-R2 factor [43], the equigranular granite plots dominantly in the anorogenic field as well as the microgranite. The granodiorite shows wide distribution from post-collisional to syn-collisional and late orogenic fields (Figure 14(a)).

Table 1. Whole rock chemical composition of selected samples from the Kitongo U occurrence.

\begin{tabular}{|c|c|c|c|c|c|c|c|c|c|c|c|c|c|c|c|c|c|c|c|}
\hline \multirow{3}{*}{ Sample ID } & \multicolumn{6}{|c|}{ Unaltered rocks } & \multicolumn{4}{|c|}{$\begin{array}{l}\text { Altered and weakly } \\
\text { mineralized rocks }\end{array}$} & \multicolumn{9}{|c|}{ Mineralized rocks } \\
\hline & KIT & KIT & $\mathrm{KS}$ & $\mathrm{KS}$ & $\mathrm{KS}$ & $\mathrm{KS}$ & $\mathrm{KS}$ & $\mathrm{KS}$ & $\mathrm{KS}$ & $\mathrm{KS}$ & $\mathrm{KS}$ & $\mathrm{KS}$ & $\mathrm{KS}$ & $\mathrm{KS}$ & $\mathrm{KS}$ & $\mathrm{KS}$ & $\mathrm{KS}$ & KS & KS \\
\hline & $1-1$ & $3-3$ & $9-1$ & $17-2$ & $17-3$ & $5-4$ & 4-3 & 4-4 & $5-3$ & 22 & $2-1$ & $3-1$ & $7-1$ & $8-1$ & $8-2$ & 10 & $11-2$ & $12-2$ & 23 \\
\hline
\end{tabular}

Major elements

$(\mathrm{wt} \%)$

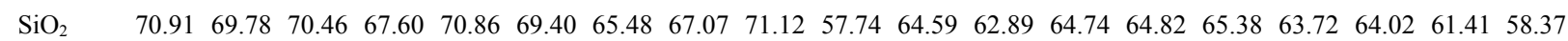

$\begin{array}{llllllllllllllllllll}\mathrm{TiO}_{2} & 0.30 & 0.27 & 0.50 & 0.51 & 0.46 & 0.27 & 0.28 & 0.30 & 0.26 & 0.51 & 0.32 & 0.26 & 0.46 & 0.32 & 0.31 & 0.34 & 0.28 & 0.57 & 0.60\end{array}$

$\begin{array}{lllllllllllllllllllllll}\mathrm{Al}_{2} \mathrm{O}_{3} & 13.16 & 14.83 & 14.63 & 14.02 & 13.51 & 14.67 & 18.10 & 18.59 & 14.90 & 18.06 & 18.17 & 17.52 & 17.13 & 18.14 & 18.02 & 18.06 & 18.03 & 17.37 & 16.57\end{array}$

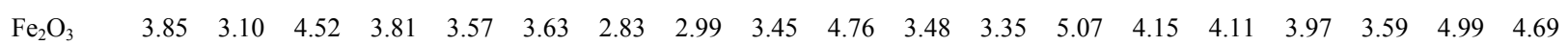

$\begin{array}{lllllllllllllllllllll}\mathrm{MnO} & 0.061 & 0.063 & 0.096 & 0.063 & 0.051 & 0.063 & 0.039 & 0.044 & 0.063 & 0.087 & 0.061 & 0.067 & 0.067 & 0.071 & 0.065 & 0.090 & 0.079 & 0.096 & 0.121\end{array}$

$\begin{array}{llllllllllllllllllll}\mathrm{MgO} & 0.12 & 0.20 & 0.98 & 1.03 & 0.85 & 0.02 & 0.03 & 0.04 & 0.03 & 1.07 & 0.16 & 0.08 & 0.10 & 0.07 & 0.09 & 0.09 & 0.11 & 0.96 & 0.93\end{array}$

$\begin{array}{lllllllllllllllllllllll}\mathrm{Cr}_{2} \mathrm{O}_{3} & 0.054 & 0.035 & 0.039 & 0.031 & 0.053 & 0.037 & 0.027 & 0.026 & 0.022 & 0.038 & 0.027 & 0.034 & 0.035 & 0.027 & 0.029 & 0.037 & 0.028 & 0.028 & 0.035\end{array}$

$\begin{array}{llllllllllllllllllll}\mathrm{CaO} & 0.81 & 0.76 & 1.46 & 1.88 & 1.76 & 0.34 & 0.24 & 0.24 & 0.38 & 1.82 & 1.40 & 0.94 & 0.70 & 0.71 & 0.63 & 1.33 & 1.66 & 1.81 & 3.70\end{array}$

$\begin{array}{llllllllllllllllllllllll}\mathrm{Na}_{2} \mathrm{O} & 4.33 & 5.19 & 5.58 & 4.80 & 7.13 & 6.63 & 9.95 & 10.87 & 8.53 & 9.58 & 10.58 & 10.05 & 10.36 & 10.72 & 10.87 & 10.92 & 10.66 & 9.75 & 9.03\end{array}$

$\begin{array}{llllllllllllllllllll}\mathrm{K}_{2} \mathrm{O} & 5.32 & 5.21 & 2.81 & 3.76 & 0.53 & 2.81 & 0.05 & 0.06 & 0.10 & 0.97 & 0.09 & 0.10 & 0.10 & 0.10 & 0.11 & 0.11 & 0.08 & 0.60 & 0.50\end{array}$

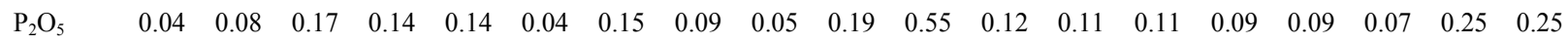

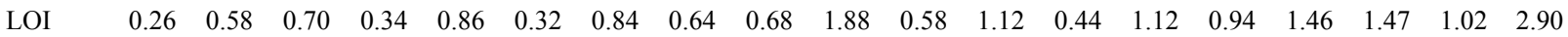

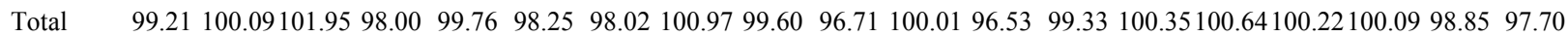

Trace elements

(ppm)

\begin{tabular}{|c|c|c|c|c|c|c|c|c|c|c|c|c|c|c|c|c|c|c|c|}
\hline $\mathrm{Sn}$ & 2 & 2 & 2 & 4 & 3 & 2 & 2 & 1 & 2 & 2 & 2 & 1 & 3 & 1 & b.d.l. & 2 & 3 & 2 & 2 \\
\hline $\mathrm{Ba}$ & 107.2 & 541.1 & 689.1 & 562.8 & 520.5 & 45.6 & 45.3 & 50.2 & 41.0 & 647.2 & 143.6 & 196.5 & 56.4 & 22.6 & 29.2 & 29.0 & 24.3 & 245.5 & 448.9 \\
\hline $\mathrm{Nb}$ & 112.9 & 150.4 & 91.1 & 97.3 & 63.0 & 77.9 & 149.3 & 130.9 & 55.0 & 124.8 & 91.8 & 173.9 & 83.0 & 43.9 & 40.6 & 52.3 & 54.9 & 157.6 & 96.6 \\
\hline $\mathrm{Ta}$ & 0.5 & 1.2 & 1.4 & 2.2 & 1.7 & 0.3 & 0.8 & 0.9 & 0.4 & 0.9 & 1.0 & 1.0 & 0.8 & 2.6 & 1.4 & 1.0 & 0.6 & 0.7 & 1.2 \\
\hline $\mathrm{Zr}$ & 692 & 484 & 400 & 333 & 313 & 757 & 559 & 682 & 638 & 521 & 638 & 681 & 1189 & 938 & 888 & 846 & 737 & 482 & 365 \\
\hline Y & 35.3 & 40.7 & 33.0 & 59.9 & 39.9 & 27.4 & 27.5 & 29.0 & 24.8 & 27.9 & 58.7 & 39.8 & 38.8 & 20.4 & 21.5 & 36.6 & 31.3 & 36.7 & 36.7 \\
\hline $\mathrm{Sr}$ & 64.0 & 105.7 & 181.7 & 267.1 & 253.6 & 13.4 & 60.9 & 50.5 & 12.6 & 474.4 & 211.7 & 59.1 & 41.1 & 62.1 & 56.8 & 117.3 & 151.0 & 181.8 & 508.3 \\
\hline $\mathrm{Rb}$ & 56.3 & 49.6 & 65.5 & 92.8 & 21.2 & 31.3 & 1.9 & 1.8 & 3.5 & 39.4 & 2.2 & 3.0 & 1.4 & 2.8 & 3.0 & 1.9 & 1.6 & 22.4 & 22.5 \\
\hline $\mathrm{Ga}$ & 19.2 & 22.0 & 18.6 & 23.6 & 22.2 & 24.0 & 29.9 & 30.2 & 25.1 & 24.8 & 27.0 & 24.0 & 29.7 & 28.3 & 28.6 & 27.9 & 27.0 & 22.9 & 21.6 \\
\hline $\mathrm{Zn}(\mathrm{b})$ & 80 & 110 & 91 & 126 & 95 & 113 & 46 & 82 & 113 & 118 & 101 & 165 & 132 & 57 & 78 & 111 & 100 & 129 & 107 \\
\hline $\mathrm{Hf}$ & 16 & 13 & 9 & 10 & 10 & 17 & 14 & 16 & 14 & 12 & 16 & 15 & 26 & 18 & 19 & 18 & 16 & 13 & 10 \\
\hline W & 1.0 & 1.7 & 0.7 & b.d.l. & b.d.1. & 0.9 & b.d.l. & b.d.l. & b.d.l. & 0.5 & b.d.l. & 0.5 & b.d.l. & 0.5 & 0.8 & b.d.l. & b.d.1. & b.d.l. & 0.5 \\
\hline
\end{tabular}


Continued

\begin{tabular}{|c|c|c|c|c|c|c|c|c|c|c|c|c|c|c|c|c|c|c|c|}
\hline Th & 12.3 & 6.7 & 6.5 & 5.9 & 5.7 & 12.3 & 10.1 & 10.6 & 14.0 & 10.6 & 8.2 & 6.9 & 18.4 & 10.1 & 10.2 & 9.8 & 8.5 & 5.6 & 6.2 \\
\hline $\mathrm{U}$ & 4.2 & 1.2 & 2.4 & 2.6 & 2.0 & 5.1 & 20.5 & 18.3 & 11.3 & 14.9 & 651.1 & 627.9 & 88.9 & 188.8 & 176.0 & 119.5 & 513.8 & 536.0 & 147 \\
\hline $\mathrm{Li}(\mathrm{b})$ & b.d.1. & b.d.l. & 29 & 26 & 11 & b.d.l. & b.d.l. & b.d.1. & b.d.l. & 29 & 9 & b.d.l. & 10 & b.d.l. & 2 & 2 & 6 & 9 & 13 \\
\hline V & 8.3 & b.d.l. & 44.9 & 33.8 & 29.2 & b.d.l. & 6.2 & 5.3 & b.d.l. & 38.3 & 13.5 & 7.2 & 10.9 & b.d.l. & 5.3 & 6.4 & 9.0 & 34.8 & 33.7 \\
\hline $\mathrm{Pb}$ (b) & 13 & 1 & 1 & 1 & 1 & 10 & 6 & 8 & 13 & 12 & 115 & 55 & 22 & 18 & 20 & 20 & 16 & 52 & 22 \\
\hline \multicolumn{20}{|c|}{$\begin{array}{l}\text { Rare earth } \\
\text { lements (ppm) }\end{array}$} \\
\hline $\mathrm{La}$ & 198.4 & 68.6 & 49.2 & 42.7 & 49.1 & 173.2 & 148.4 & 149.9 & 213.1 & 86.5 & 107.8 & 139.2 & 237.7 & 184.6 & 184.5 & 184.6 & 160.9 & 28.8 & 58.6 \\
\hline $\mathrm{Ce}$ & 408.1 & 150.1 & 103.9 & 98.6 & 100.7 & 369.9 & 316.8 & 313.9 & 443.0 & 176.4 & 223.2 & 279.7 & 488.3 & 348.0 & 360.6 & 373.1 & 321.2 & 62.9 & 118.7 \\
\hline $\operatorname{Pr}$ & 46.8 & 18.2 & 12.2 & 12.5 & 11.3 & 40.5 & 37.0 & 36.7 & 48.8 & 20.1 & 26.9 & 21.6 & 53.2 & 41.1 & 41.2 & 42.0 & 35.8 & 7.9 & 13.8 \\
\hline $\mathrm{Nd}$ & 173.2 & 71.5 & 47.4 & 50.3 & 40.8 & 149.6 & 137.1 & 134.3 & 177.9 & 73.0 & 103.1 & 105.7 & 191.3 & 150.7 & 149.8 & 153.7 & 131.2 & 33.5 & 52.1 \\
\hline $\mathrm{Sm}$ & 26.2 & 13.8 & 8.7 & 11.6 & 8.2 & 22.8 & 20.4 & 19.8 & 25.7 & 11.1 & 18.4 & 18.3 & 26.3 & 20.1 & 20.3 & 22.2 & 19.6 & 7.2 & 9.4 \\
\hline $\mathrm{Eu}$ & 0 . & 1.0 & 0.9 & 0.9 & 0.9 & 0.2 & 0.4 & 0.4 & 0.2 & 0.9 & 1.7 & 1.0 & 0.3 & 0.2 & 0.2 & 0.3 & 0.2 & 0.9 & 1.4 \\
\hline $\mathrm{Gd}$ & 19.6 & 12.4 & 8.1 & 11.4 & 8.1 & 16.7 & 13.8 & 13.6 & 18.4 & 8.8 & 17.2 & 13.4 & 19.5 & 14.2 & 14.4 & 17.2 & 15.0 & 7.0 & 8.5 \\
\hline $\mathrm{Tb}$ & 2.0 & 1.7 & 1.1 & 1.8 & 1.2 & 1.7 & 1.5 & 1.5 & 1.7 & 1.0 & 2.3 & 1.2 & 2.0 & 1.2 & 1.2 & 1.8 & 1.6 & 1.1 & 1.1 \\
\hline Dy & 9.3 & 9.5 & 6.3 & 10.9 & 7.0 & 7.2 & 6.9 & 7.1 & 7.3 & 5.5 & 12.5 & 10.7 & 8.9 & 4.6 & 4.8 & 8.7 & 7.4 & 6.7 & 6.7 \\
\hline Но & 1.6 & 1.7 & 1.2 & 2.1 & 1.4 & 1.2 & 1.2 & 1.3 & 1.1 & 1.1 & 2.2 & 2.0 & 1.6 & 0.8 & 0.9 & 1.5 & 1.3 & 1.3 & 1.4 \\
\hline $\mathrm{Er}$ & 4.5 & 4.8 & 3.6 & 6.2 & 4.0 & 3.6 & 3.2 & 3.5 & 3.3 & 3.2 & 5.9 & 5.8 & 4.9 & 2.5 & 2.8 & 4.4 & 3.7 & 4.0 & 3.9 \\
\hline $\mathrm{Tm}$ & 0.6 & 0.6 & 0.5 & 0.9 & 0.6 & 0.5 & 0.4 & 0.5 & 0.4 & 0.4 & 0.7 & 0.4 & 0.7 & 0.3 & 0.4 & 0.6 & 0.5 & 0.6 & 0.6 \\
\hline $\mathrm{Yb}$ & 4.0 & 4.1 & 3.5 & 5.4 & 3.9 & 3.7 & 2.9 & 3.1 & 3.2 & 2.9 & 4.6 & 4.6 & 4.9 & 2.2 & 2.7 & 4.1 & 3.6 & 4.0 & 4.0 \\
\hline $\mathrm{Lu}$ & 0.7 & 0.6 & 0.6 & 0.8 & 0.6 & 0.7 & 0.5 & 0.5 & 0.6 & 0.5 & 0.7 & 0.8 & 0.9 & 0.4 & 0.5 & 0.7 & 0.7 & 0.7 & 0.6 \\
\hline
\end{tabular}

KREE $\quad 895.25358 .73247 .22255 .87237 .72791 .33690 .69686 .05944 .90391 .23527 .04604 .33$ 1040. 770.91784 .23814 .82702 .63166 .71280 .50 LLREE $\quad 852.95323 .19222 .32216 .61210 .94756 .17660 .22655 .00908 .81367 .96481 .01565 .56997 .20744 .72756 .57775 .88668 .87141 .35253 .87$

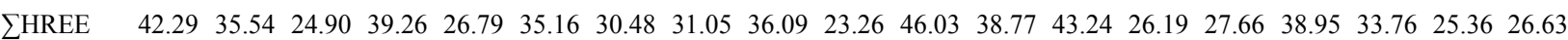

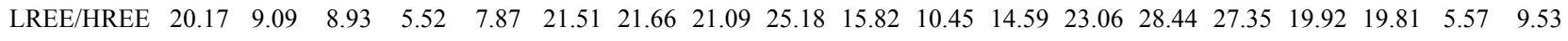

KIT1-1, KIT3-3, KS5-4, KS4-3, KS4-3, KS4-4, KS5-3, KS2-1, KS3-1, KS7-1, KS8-1, KS8-2, KS10, KS11-2 (equigranular granite); KS17-2, KS17-3 (porphyritic granite); KS9-1, KS22, KS12-2, KS23 (faults rocks). (b) Elements measured by ICP-AES.
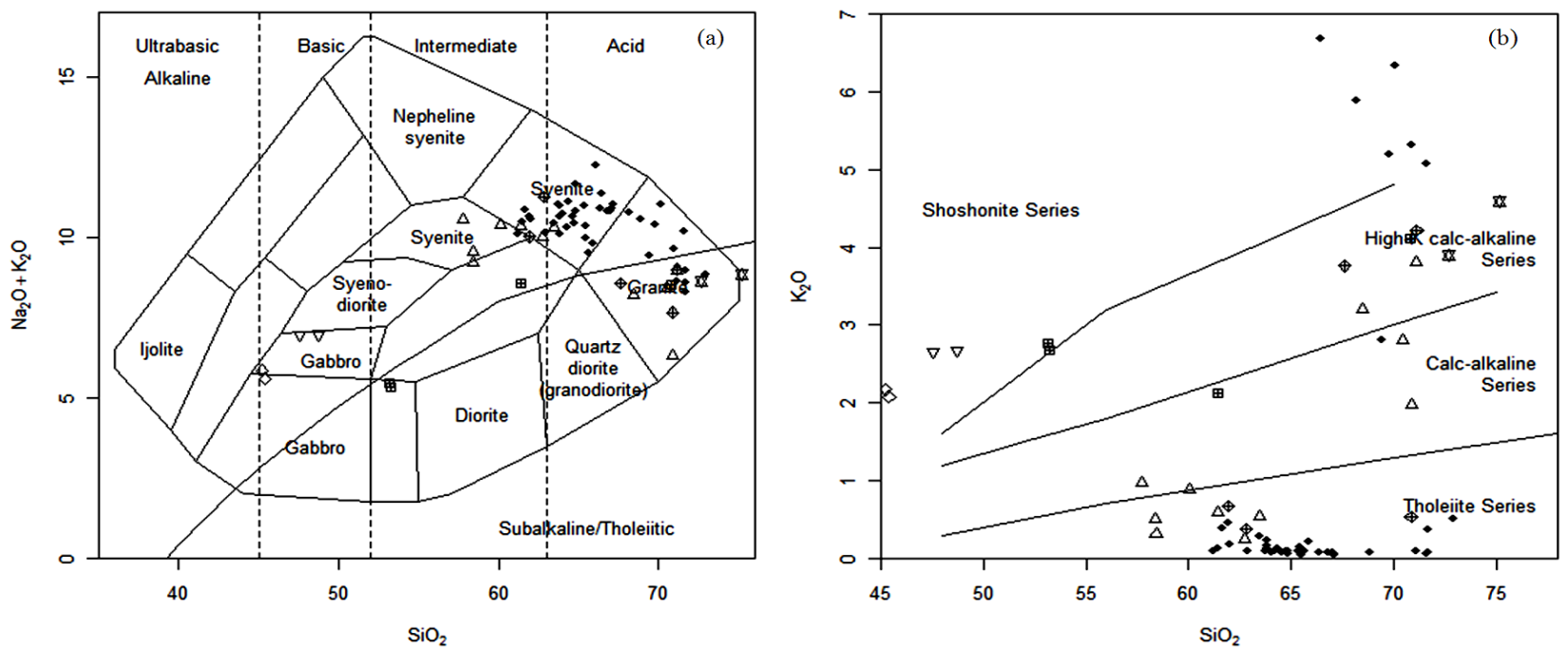

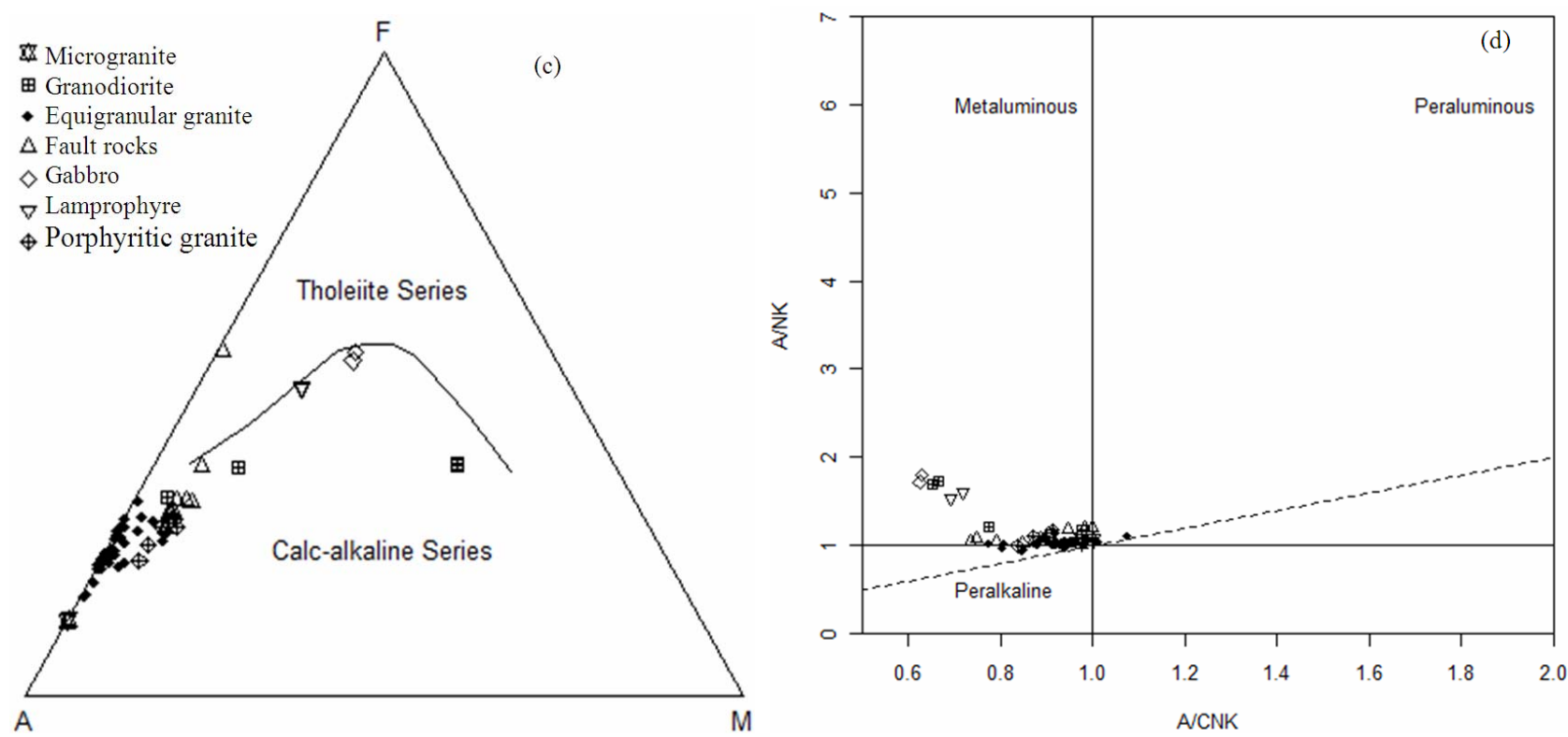

Figure 12. (a) Total alkali-silica (TAS) diagram [38] for chemical classification and nomenclature of the Kitongo granitoids; (b) $\mathrm{K}_{2} \mathrm{O}$ vs. $\mathrm{SiO}_{2}$ diagram [39] illustrating the spread of the Kitongo granitoids from tholeiitic to shoshonitic series , see the text for more explanations; (c) AFM diagram of Kitongo granitoids [40]; (d) Shand's molar parameters $\mathrm{Al}_{2} \mathrm{O}_{3} /\left(\mathrm{CaO}^{2} \mathrm{Na}_{2} \mathrm{O}+\right.$ $\left.\mathrm{K}_{2} \mathrm{O}\right)$ versus $\mathrm{Al}_{2} \mathrm{O}_{3} /\left(\mathrm{Na}_{2} \mathrm{O}+\mathrm{K}_{2} \mathrm{O}\right)$ [A/CNK vs. $\left.\mathrm{A} / \mathrm{NK}\right]$ of Kitongo granitoids [41].
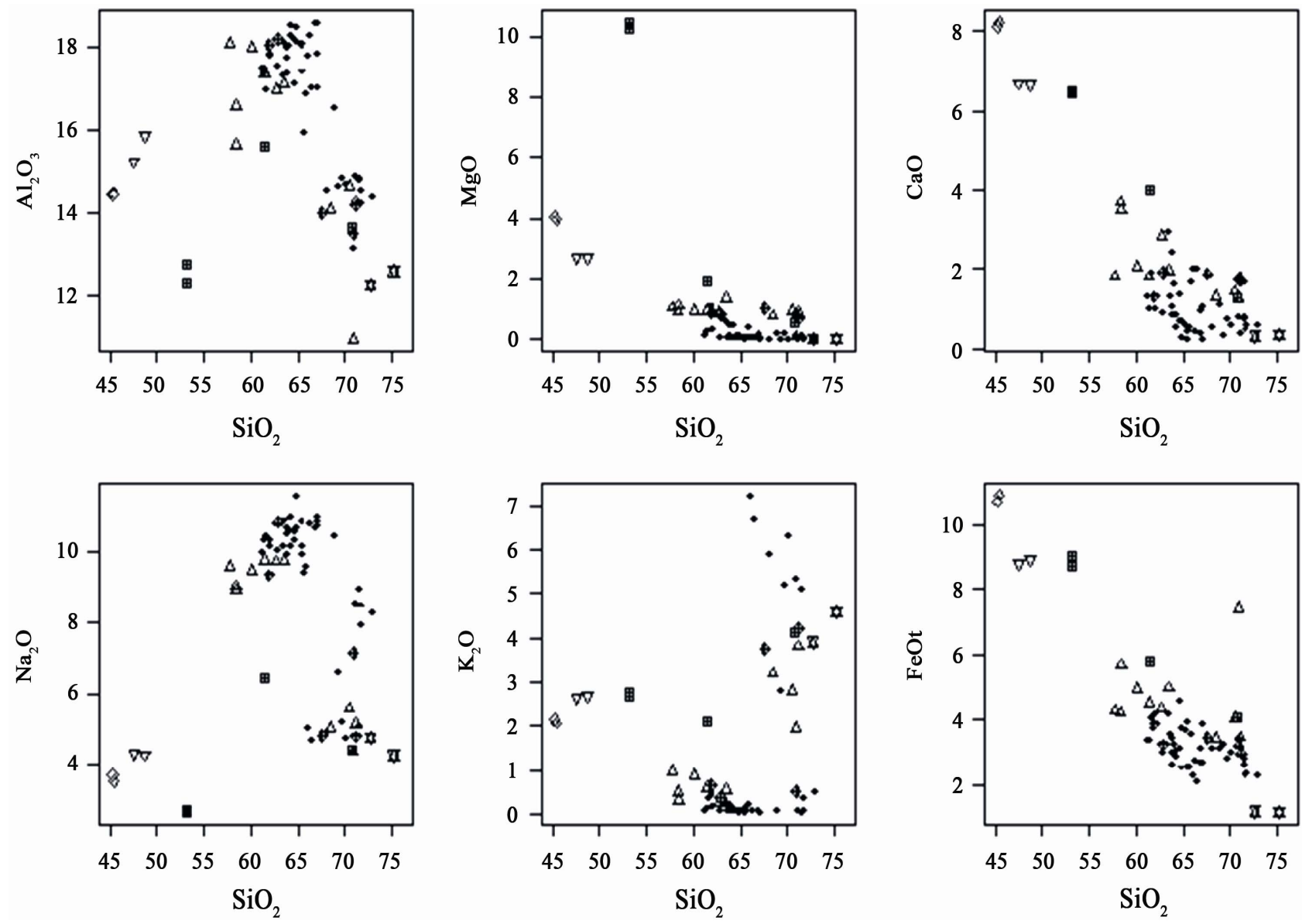

Figure 13. Harker variation diagrams of selected $\mathrm{SiO}_{2}$ vs. major oxides for Kitongo granitoids. Symbols are the same as in Figure 12. 

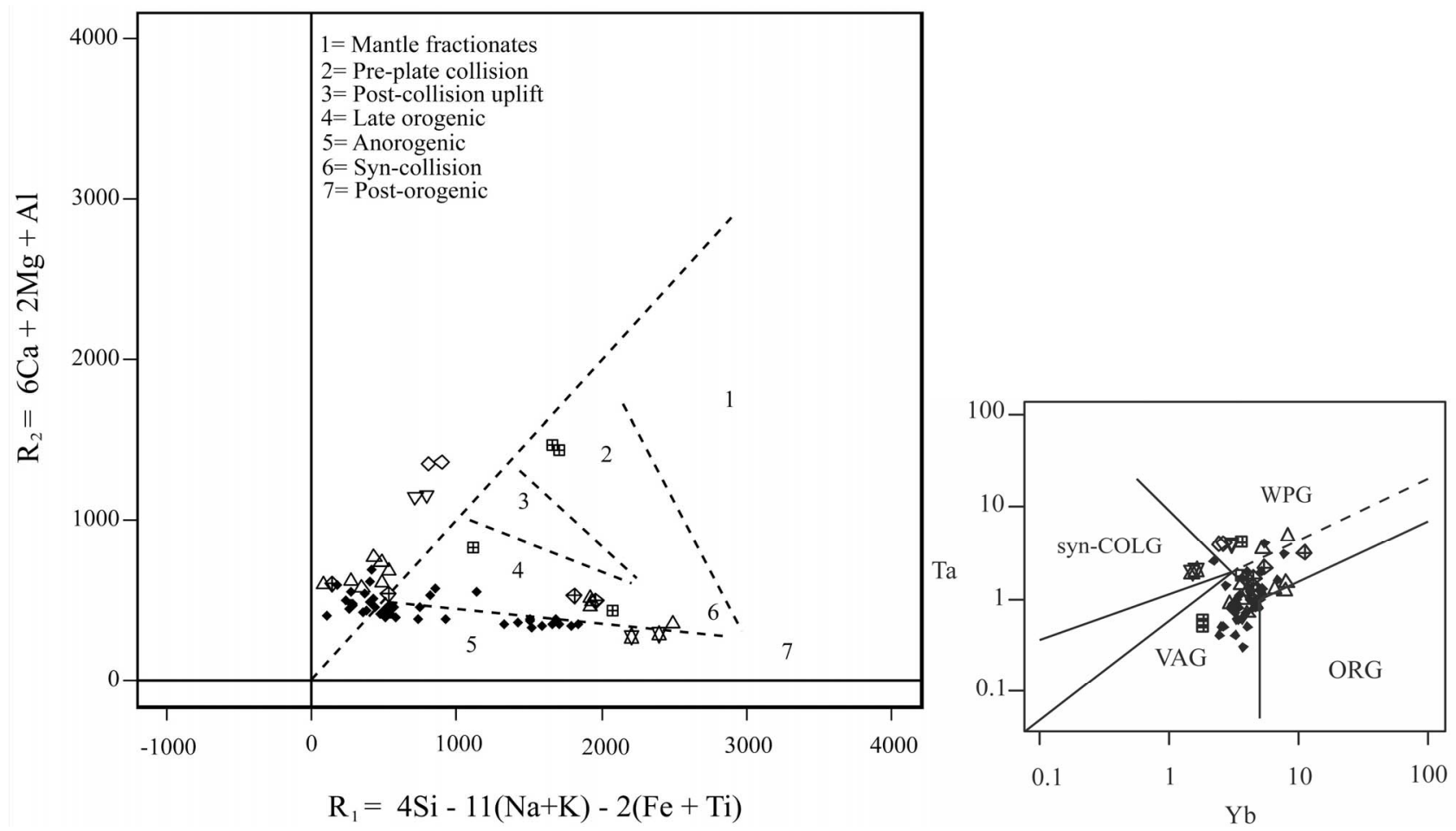

Figure 14. (a) R1-R2 multicationic [43] diagram showing various tectonic fields [44]; (b) Ta-Yb discriminant diagram showing tectonic settings of Kitongo granitoids [45]. Symbols are the same as in Figure 12.

\subsection{Trace Elements}

The $\mathrm{U}$ content of the equigranular granite reaches a maximum value of $651 \mathrm{ppm}$ while the Th concentration is low (18 ppm). The HFSE show moderate to high enrichment in the granites (Ce up to $488 \mathrm{ppm}), \mathrm{Zr}$ (1189 ppm), $\mathrm{Y}(59.9 \mathrm{ppm}), \mathrm{Nb}$ (173.9 ppm), $\mathrm{Pb}$ (115 ppm) while the transition elements exhibit moderate enrichment (Zn: 46 - 165 ppm; Ga: 19 - 30 ppm). Amongst the large ion lithophile elements (LILE), Rb (1.4 - 92.8 ppm) $\mathrm{Sr}$ (13.4 $267.1 \mathrm{ppm})$ and $\mathrm{Ba}(22.6-562.8 \mathrm{ppm})$ show moderate to high abundances. Predominance of $\mathrm{Sr}$ over $\mathrm{Rb}$ is indicated by low $\mathrm{Rb} / \mathrm{Sr}$ ratio (average 0.31 ) which is more akin to a mantle source, while $\mathrm{Rb} / \mathrm{Ba}$ and $\mathrm{Sr} / \mathrm{Ba}$ ratios are 0.14 and 1.48 , respectively. The fault rocks show different trace element characteristics when compared to the fresh granite (Table 1). Uranium concentration here ranges from 2.4 to $536 \mathrm{ppm}$ while Th values range from 5.6 to $10.6 \mathrm{ppm}$. The subduction-related arc magmatism is indicated by $\mathrm{Yb}$ and $\mathrm{Ta}$ plot [45] where all of the study rocks spread in fields of volcanic arc granite (VAG) and within plate granite (WPG), except for the microgranite that falls in the field of syn-collisional granite (syn-COLG) (Figure 14(b)).

\subsection{Rare Earth Elements}

With regards to REE geochemistry, all the samples have moderate to high LREE contents and comparatively low content of HREE. The REE data for granites (equi- and porphyritic granites) of the Kitongo $\mathrm{U}$ occurrence show enrichment (237.7 to $1040.4 \mathrm{ppm}$; average $673.7 \mathrm{ppm}$ ). The granites exhibit similar REE, LREE and HREE distribution patterns, high LREE abundances and comparatively low HREE abundances. In addition chondrite-normalized REE patterns (Figure 15(a)) for these granites are characterized by moderate fractionation of LREE to HREE with $(\mathrm{La} / \mathrm{Lu})_{\mathrm{N}}$ and $(\mathrm{Ce} / \mathrm{Yb})_{\mathrm{N}}$ values ranging from 5.84 to 43.53 and 4.75 to 40.27 , respectively $(\mathrm{La} / \mathrm{Sm})_{\mathrm{N}}$ ratios of 2.32 to 5.78 . The chondrite- normalized REE patterns for the fault rocks (Figure 15(b)) are characterized by moderate fractionation of LREE to HREE with $(\mathrm{La} / \mathrm{Lu})_{\mathrm{N}}$ and $(\mathrm{Ce} / \mathrm{Yb})_{\mathrm{N}}$ values ranging from 4.43 to 19.48 and 4.05 to 15.98 , respectively. Both the granites and the fault rocks of the Kitongo area have strong negative $\mathrm{Eu}$ anomalies (Figures 15(a) and (b)) but this is more pronounced in the granite $\left(\mathrm{Eu} / \mathrm{Eu}^{*}=0.03\right.$ to 0.33$)$ as compared to the fault rocks $\left(\mathrm{Eu} / \mathrm{Eu}^{*}=0.28\right.$ to 0.48$)$. The negative Eu anomaly in the granites typically suggests feldspar fractionation or indicates separation of melt from a plagioclase-rich source.

\section{Hydrothermal Alteration}

The hydrothermal alterations experienced by the host granite and associated fault rocks such as albitization, haematitization and uranium mineralization are discernable from the whole rock geochemical data. The alteration of K-feldspar to albite is evidenced by a sharp decrease in $\mathrm{K}$ con- 
centration (from $\sim 5.32 \mathrm{wt} \%$ in the fresh rock to $\sim 0.08$ $\mathrm{wt} \%$ in the ore zone granite, and from $2.4 \mathrm{wt} \%$ in the fresh rock to $\sim 0.5 \mathrm{wt} \%$ in the mineralized fault rock) and by corresponding increase in $\mathrm{Na}$ (from $\sim 4.33 \mathrm{wt} \%$ to $10.92 \mathrm{wt} \%$ in the fresh granite and from $\sim 5.58 \mathrm{wt} \%$ to $9.75 \mathrm{wt} \%$ in fault rocks (Table 1, Figure 16(a)). The decrease of $\mathrm{K}$ is probably enhanced by the chloritization of biotite although the amount of biotite in the fresh rocks is relatively small. Fe and $\mathrm{Mg}$ vary slightly from $\sim 3.10 \mathrm{wt} \%$ to $\sim 5.07 \mathrm{wt} \%$ and $\sim 0.02 \mathrm{wt} \%$ to $\sim 0.16 \mathrm{wt} \%$, respectively, from fresh granite to ore zone granite, and from $\sim 3.81 \mathrm{wt} \%$ to $4.99 \mathrm{wt} \%$ and $\sim 0.98$ to $\sim 0.96 \mathrm{wt} \%$ respectively from the barren to the mineralized fault rock. Al increases (from $\sim 13.16 \mathrm{wt} \%$ in unaltered granite to approx. 18.17 in mineralized granite) and (from $\sim 14.63$ $\mathrm{wt} \%$ to $\sim 17.37 \mathrm{wt} \%$ respectively from barren to mineralized fault rocks). $\mathrm{P}_{2} \mathrm{O}_{5}$ slightly increase (from $\sim 0.04$ $\mathrm{wt} \%$ to $0.55 \mathrm{wt} \%$ from barren to mineralized granite zone) and (from $\sim 0.17 \mathrm{wt} \%$ to $\sim 0.25 \mathrm{wt} \%$ respectively in barren and mineralized fault rocks. The increase of $\mathrm{P}_{2} \mathrm{O}_{5}$ in ore zones signifies that apatite continued to form during the main ore stage. Formation of calcite is reflected by increased $\mathrm{Ca}$ contents (from average $\sim 0.34 \mathrm{wt} \%$

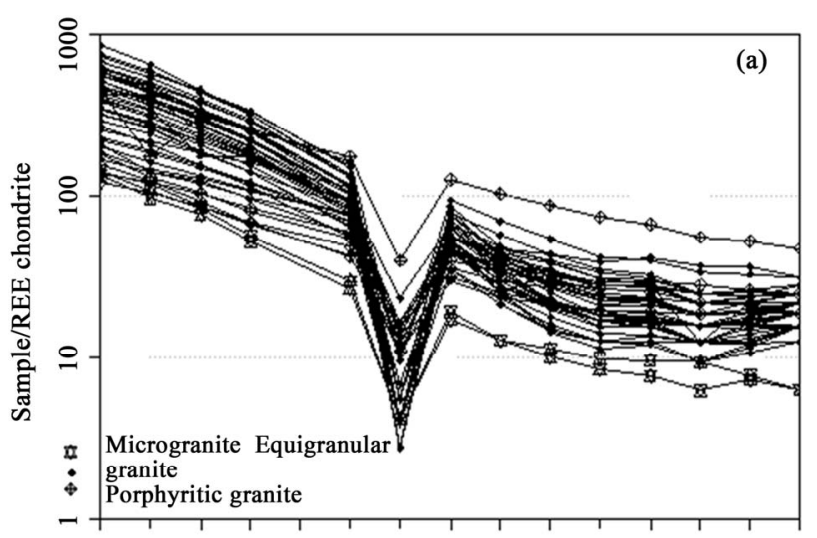

La Ce Pr Nd Pm Sm Eu Gd Tb Dy Ho Er Tm Yb Lu

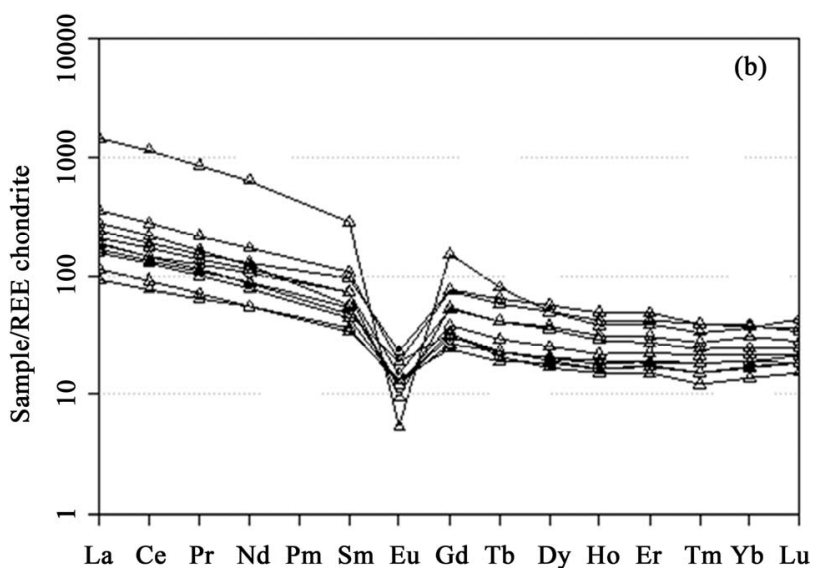

Figure 15. (a) Chondrite-normalized REE patterns of Kitongo granite; (b) Chondrite-normalized REE patterns of faults rocks. Normalized values [46].
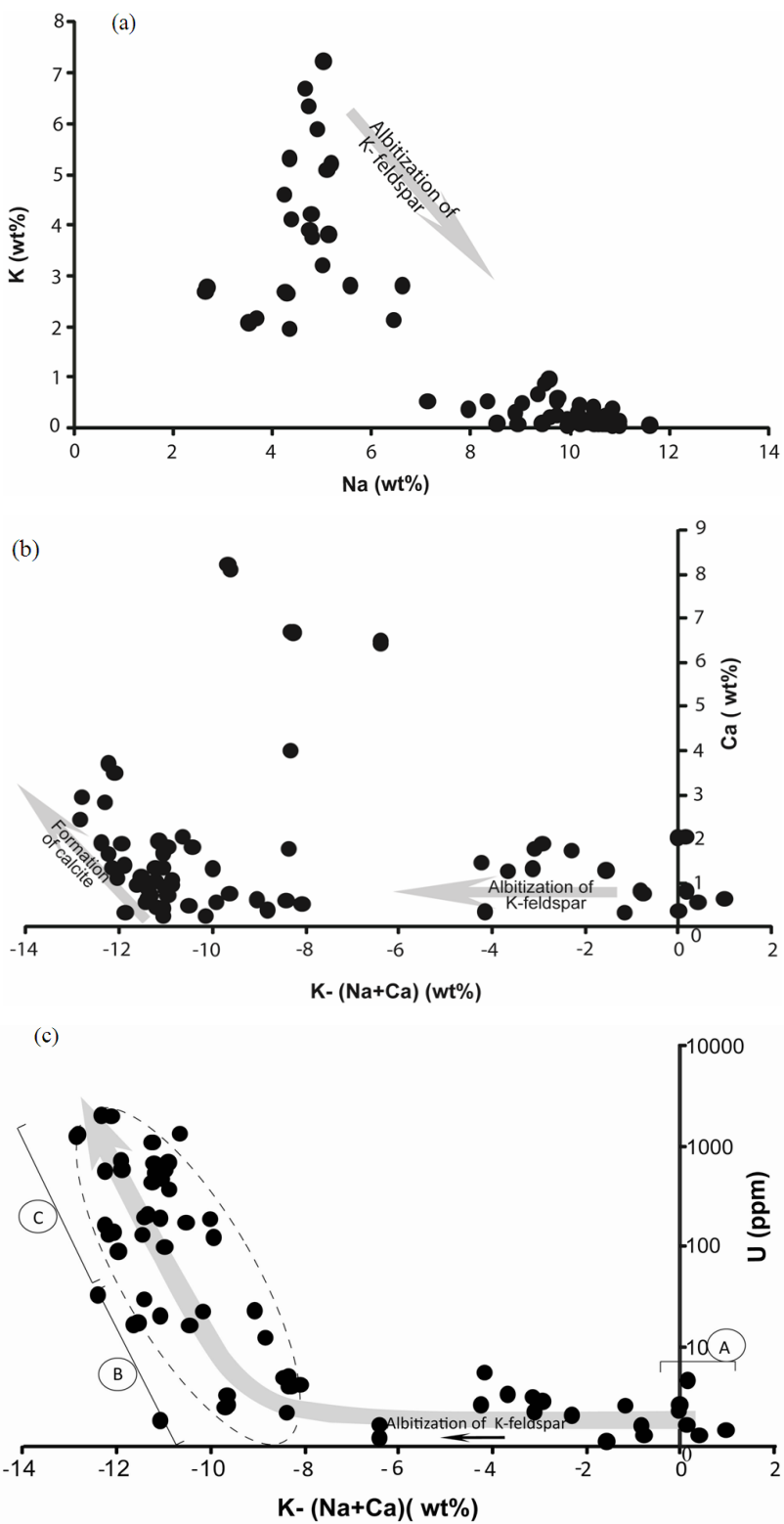

Figure 16. Whole rock geochemistry of granitoids from Kitongo uranium occurrence, with $\mathrm{K}, \mathrm{Ca}$, and $\mathrm{U}$ plotted as function of degree of albitization (expressed as $\mathrm{K}$ - ( $\mathrm{Na}+$ Ca). (a)-(c) mineral change: $A=$ unaltered rocks; $B=$ altered and weakly mineralized rocks; $C=$ highly altered and mineralized rocks, formation of U-mineral. The evolution trend is highlighted by arrowed hyperbole curve. The ellipse shows the positive correlation between albitization and $U$ mineralization.

to average $\sim 1.6 \mathrm{wt} \%$ with few samples of up to $6.5 \mathrm{wt} \%$ (Figure 16(a)). The granite host rock $U$ concentrations vary from 1.2 to $5.1 \mathrm{ppm}$ (Table 1) with an average of $2.99 \mathrm{ppm}$, approximately equal to those in typical granite which contains $\sim 3.2 \mathrm{ppm}$ [47] and therefore are not $U$ fertile granite. The formation of $U$ minerals is reflected by the increase in $U$ concentration from an average of $\sim 3.40 \mathrm{ppm}$ to $\sim 651 \mathrm{ppm}$ in ore zones (Table 1 and Figure 
16(c)). Figure 16(c) shows that the main U-ore stage is directly related to albitization as an increase in $\mathrm{U}$ content positively correlates with the decrease in K. The increase of $\mathrm{Ca}$ contents follows almost a similar pattern to that of $\mathrm{U}$, increasing slightly during albitization and correlating positively with albitization expressed as $\mathrm{K}-$ $(\mathrm{Na}+\mathrm{Ca})$ more at low $\mathrm{K}$ concentrations (Figure 16(b)). Considering the evolution of $\mathrm{K}, \mathrm{Na}$ and $\mathrm{Ca}$ concentrations (Figure 16), it appears that $\mathrm{Na}$ was continuously added to the system, whereas $\mathrm{Ca}$ increased only after initial albitization was almost complete although some samples show increasing $\mathrm{Ca}$ before this stage. $\mathrm{K}, \mathrm{Rb}$, $\mathrm{Nb}, \mathrm{Ba}$ and $\mathrm{Si}$ seem to be the only elements removed from the system whereas $\mathrm{Pb}, \mathrm{Zn}, \mathrm{Ga}, \mathrm{Hf}, \mathrm{Sr}, \mathrm{Fe}, \mathrm{Al}, \mathrm{P}$ and $\mathrm{Zr}$ were added during alteration and mineralization in addition to $\mathrm{U}, \mathrm{Na}$ and $\mathrm{Ca}$ (Table 1).

Variation in $\mathrm{Th} / \mathrm{U}$ ratios (0.01 - 5.64 and 0.01 - 2.72) with lower average values (1.26 and 0.87$)$ respectively in granite and fault rock as compared to global $\mathrm{Th} / \mathrm{U}$ ratio of $3.8[48,49]$ suggests $U$ mobilization in the system leading to either selective enrichment or depletion. Figure 17 however suggests that there is no increase of Th contents with the increase of $\mathrm{U}$. Thus all the recorded radiometric anomalies are due to uranium.

\section{Discussion}

\subsection{Petrology and Rock Classification}

Pluton margins are likely to be broadly schistose or mylonitic in plutons emplaced diapirically when the body was more than $70 \%$ crystallized notably along zones of ductile shear [50]. The syn- to late-tectonic Kogué massif in this study is a diapir whose emplacement was favored by the density contrast between the massif and the country rock under greenschist facies metamorphic conditions [36]. The detailed field mapping presented here

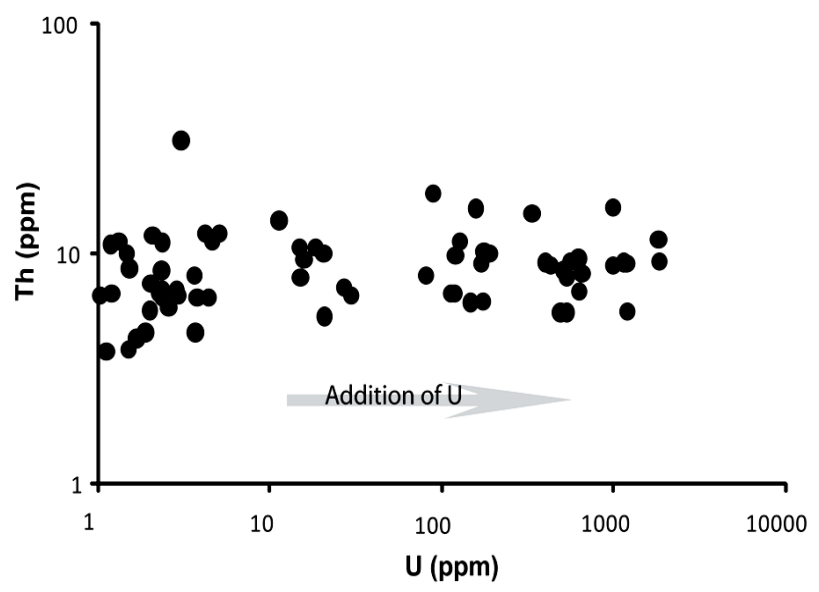

Figure 17. Whole rock $T h$ and $U$ concentration of granitoids from Kitongo uranium occurrence. No increase of Th contents is observed with the increase of $U$. shows that the lithology at the Kitongo U occurrence comprised granodiorite, granite locally associated with mafic dikes and fault rocks made up of a mélange of two distinct rock types: the metamorphic rocks of the Poli Group and the Kogué granite.

The Kitongo granitoids belong to the tholeiite to shoshonite series exhibiting low to high $\mathrm{K} / \mathrm{Rb}$ ratios respecttively. It is proposed that the magma which gave rise to the tholeiittic series, came from an intermediate differentiating magma. The probable explanation for the tholeiitic character of some samples of both granite and fault rocks is hydrothermal alteration that lowered the $\mathrm{K}$ content of the rocks. I-type granites are metaluminous to weakly peraluminous (ASI between 0.99 and 1.8) and commonly contain biotite, hornblende and titanium [51]. The weakly aluminous and peralkaline Kitongo granitoids have clear I-type characteristics. Further, these rocks were generated at a collisional tectonic environment involving lower crustal-upper mantle source material, which underwent fractional crystallization as evidence by anthipathetic relationship of $\mathrm{SiO}_{2}$ with $\mathrm{CaO}, \mathrm{FeO}^{\mathrm{t}}, \mathrm{MgO}$ and $\mathrm{Al}_{2} \mathrm{O}_{3}$ and sympathetic relationship between $\mathrm{K}_{2} \mathrm{O}$ and $\mathrm{Na}_{2} \mathrm{O}$.

\subsection{Trace and Rare Earth Elements}

In the $\mathrm{Yb}$ and $\mathrm{Ta}$ plot [45], the studied rocks spread in fields of volcanic arc granite (VAG) and within plate granite (WPG), except for the microgranite that falls in the field of syn-collisional granite (syn-COLG). This overlap sample data set in VAG and WPG fields is perhaps produced by both the differentiation trend and/or characteristics of the source rocks [52]. The REE data for granites (equi- and porphyritic granites) of the Kitongo U occurrence show an enrichment (237.7 to $1040.4 \mathrm{ppm}$; average $673.7 \mathrm{ppm}$ ) compared to the average global REE content of about $250 \mathrm{ppm}$ for granites in general [53]. Note that the sum of REE in acid and intermediate rocks ranges from $220-350 \mathrm{ppm}$ [54] and their abundance in the upper crust is $156 \mathrm{ppm}$ [48]. The REE enrichment in the Kitongo granite is similar to the REE enrichment in the granite rocks of Ado-Ekiti-Akure area, SW Nigeria [55] and the Pan-African granites of Obudu Plateau Southeastern Nigeria [56] but more than four times higher than those for the No. 302 uranium deposit in Northern Guangdong, South China [57] and more than four to five times lower than those of the granitoids of the Kinwat Crystalline Inlier, Nanded and Yeotmal Districts Maharashtra [58]. In addition, the granites at Kitongo show LREE-enrichment compared to the composition of the average upper crust. LREE-enrichment is common in calc-alkaline rocks $[59,60]$. Eu depletion depicted by a strong Euanomaly in both mineralized and barren granitoids and the fault rocks suggests that these rocks have experienced feldspar differentiation. 


\subsection{Structure and Structural Control on U Mineralization}

The internal fabric of the pluton is linked to both magmatic features developed during emplacement and deformation [61-66]. The strong foliation recorded within the fault rocks and the Poli Group strikes N050-080E and dipping $70^{\circ} \mathrm{SE}$ (Figure 6 and Figure 7(c)) to vertical. The latter deformation is compatible with the sinistral and dextral strike-slip fault of the D2 deformation phase defined within the regional structures of the northern CAFB in $\mathrm{Ca}-$ meroon $[11,67]$. Mineral lineation has N050-070E direction and plunge values $\geq 65^{\circ} \mathrm{SE}$ and the preferred orienttation of xenoliths (N050-066 SE with dip $\left.\geq 65^{\circ} \mathrm{SE}\right)$ are both parallel to the PSF, the foliation in the fault rocks as well as the extension direction. The pitch of the lineation and sense of foliation dip show that sinistral movement in Kitongo SZ includes a reverse component that indicates oblique ascent of the Kogué granite northwestward during syntectonic emplacement ; this fact is evidenced on Figure 7(c).

Within strike-slip fault systems, synthetic (P) and antithetic (R') faults commonly intersect at high angles forming a rhomb-shaped fault network [68]. The bulk permeability structure and strength of a fault zone are controlled by preexisting and newly developed structures, the regional and local stress state, fault-zone geometry, and changes in lithology resulting from the coupling of mechanical, thermal, fluid flow, and reactive geochemical processes [69]. Fluid flow in fault zones can control the location, emplacement, and evolution of economic mineral deposits and geothermal systems [70-73]. Furthermore, many hydrothermal deposits within metallogenic belts are linearly distributed, as best illustrated by those around the Pacific Rim [74]. The Kitongo fault zone consists in a conjugate fault system overprinting the earlier ENE-WSW-trending SZ referred to as the PSF and along which mylonites are the major observed features. The Riedel fault system defines an extension direction parallel to the PSF (ENE-WSW). This fault architecture is compatible with the NW-SE stress direction controlling the nearby "Vallée des Roniers" dextral SZ (VRSZ) directed E-W and its N110 synthetic across the Kogué granite. From the Riedel model (Figure 4) and the occurrences of dextral kinematic markers in the PSF, this ductile fault could have been reactivated and operated as the VRSZ synthetic $\mathrm{P}$ fault during dextral evolution. Tectonic reactivation plays a significant role in the mineralization process by providing channel-ways coeval with block movements on deep faults/fractures which sustain hydrothermal circulation system [68]. Fault intersections over the margin of the Kitongo granite yielded to high-permeability channels having trapped the uranium mineralizing fluids, and the horizontal section of the distribution of mineralized shoots conforms to the final stage of anomalous structures of geochemical fields of hydrothermal ore deposition [75], where hydrothermal alteration led to zoning marked by alternation of variably alterated granites surrounding the mineralized core zones. The spotted Umineralization mapped here occurs at fault intersections between the Riedel fault system and the SZ and parallel to it, reflecting the deep traces of the Kitongo strike-slip faults [74].

\subsection{Relationship between Albitization and Uranium Mineralization and Type of $U$ Mineralization}

The relationship between the main alteration event and the uranium mineralization can be used for defining the genetic type of uranium occurrence [76]. Syn-ore zircon precipitated simultaneously with newly formed albite, which would suggest an immediate relationship between albitization and uranium mineralization [77]. The main uranium mineralization in similar deposits is often not related to the main albitization event but clearly removed in time from it [76]. However, the observations presented above differ from these interpretations. Field surveys have revealed a two-stage albitization over the Kitongo uranium occurrence. The second albitization event overprinting the first one was more effective at faults intersections. The whole rock geochemistry indicates that albitization was contemporaneous with uranium mineralization positively correlated. Albitization evidenced by the formation of albite, decrease of $\mathrm{K}$ within the U-bearing lithologies (granite and fault rocks $5.32-0.08 \mathrm{wt} \%$ and $2.4-0.5 \mathrm{wt} \%$ respectively) and increase of $\mathrm{Na}(4.33-10.92 \mathrm{wt} \%$ and $5.58-9.75 \mathrm{wt} \%$ respectively in granite and the fault rocks, Table 1, Figure 16) is followed by the formation of calcite. The latter increases slightly during albitization from 0.34 up to $6.5 \mathrm{wt} \%$ and positively correlates with albitization mostly where albitization was intense (Figure 16). The main uranium mineralization is thus related to the second albitization event that has overprinted the first albitization phase at fault intersections. This mineralizing event is probably associated in time with the calcite- uranium stage and it is characterized by locally abundant $U$, $\mathrm{Pb}, \mathrm{Zn}$, and $\mathrm{Ga}$ enrichment. Albitization promoted subsequent fluid circulation (for the main stage $U$ mineralization) by creating a more brittle and permeable rock assemblage. The high $U$ contents in the host rocks are not the main factor controlling the intensity of uranium mineralization. Whether the granite is associated with mineralization or not and form lean ores or high-grade ores was determined by the degree of uranium mobilization. Hydrothermal activity remobilizes fixed $U$ into fluid phase [57] and eventually transports it to favourable sites where ore precipitation is then accompanied by intense alteration processes. The early stage altered hydrothermal fluid 
is an omen for large-scale mineralization; it can not only change the state of $U$ and cause the mobile $U$ increase, but also provide a partial uranium source [78]. Thus, the Kitongo U occurrence can be classified as Na-metasomatism related, in agreement with [76,77].

\section{Conclusions}

The following conclusions can be drawn.

It has not been possible to carry out surface radiometry on the whole prospect due to vertical cliff-faces and thick overburden masking the most important parts of the area.

The main rock types at the prospected area comprise: the metavolcanic and metasedimentary unit, the fault rocks unit, the granodioritic unit and the granitic unit; U occurrence is hosted by granitic rocks that include interleaved sequence of metasedimentary and metavolcanic rocks of the collectively termed Poli Group.

Uranium shoots at the Kitongo area are controlled by ENE-WSW-trending strike-slip faults. However mineralization does not occur uniformly along this fault. The most important segments hosting uranium shoots in the area are those intersecting with late Pan-African Riedel fault system.

The Kitongo $\mathrm{U}$ occurrence in northern Cameroon is $\mathrm{Na}$ metasomatism-related and characterized by local albitization of the host rock granite (U content up to 651.5 ppm) that is part of the Kogue batholith and the and mylonitic fault rocks $\left(0.22 \% \mathrm{U}_{3} \mathrm{O}_{8}\right)$ following the shear zone. In addition, all the recorded radiometric anomalies are due to uranium.

The main uranium mineralization is related to the second albitization event that has overprinted the first albitization phase at fault intersections with SZ. This mineralizing event is probably associated in time with the calcite-uranium stage. However, the importance of the albitization to the mineralization event, in genetic terms, may be in its role as potential source for uranium. Uranium concentration in unaltered rocks at Kitongo is lower, thus it is possible that the late magmatic fluids responsible for albitization also mobilized $U$ as well as hydrothermal activity remobilizing fixed $U$ and making it available for later deposition. Thus, the uranium mineralization is post magmatic and related to hydrothermal activities and faulting events.

The identification of favorable ore hosting segments within strike-slip faults has great implication for exploration strategies.

\section{Acknowledgements}

This study is part of a $\mathrm{PhD}$ thesis by Arnaud Patrice KOUSKE at the University of Yaoundé I, Cameroon. This work could not have been completed without the assistance of Mega Uranium Cameroon PLC. The authors are thankful to Mr. Marius Van Niekerk for kind acceptance to carry out field work on Mega U concessions in northern Cameroon, and financial support for geochemical analysis. The authors are grateful to all the Mega U staff for constant encouragements. They are also grateful to Mega U' President, Mr. Stewart Taylor for kind permission to publish materials in this paper.

\section{REFERENCES}

[1] R. G. Skirrow, S. Jaireth, D. L. Huston, E. N. Bastrakov, A. Schofield, S. E. Van der Wielen and A. C. Barnicoat, "Uranium Mineral Systems, Processes, Exploration Criteria and a New Deposit Framework," Geoscience Australia Record, 2009/20, 2009.

[2] J. R. Faul, "Emerging Demand from Emerging Markets A Trader's Perspective," NEI, International Uranium Fuel Seminar Savannah, 2010.

[3] W. Zittle, L. Bölkow and J. Schindler, "Uranium Resources and Nuclear Energy," Energy Watch Group Report, EWG No.1, 2006.

http://www.energywatchgroup.com/fileadmin/global/pdf/ EWG_Report_Uranium_3-12-2006ms.pdf

[4] International Atomic Energy Agency, "Integrated Nuclear Fuel Cycle Information System (iNFCIS)," IAEA, Vienna. http://www-nfcis.iaea.org/

[5] V. Thoste, "Mineral Exploration in North Cameroon, Region of Poli," Final Report, Federal Republic of Germany, Number of Project 80.2273.3, 1985.

[6] International Atomic Energy Agency, "World Distribution of Uranium Deposits (UDEPO) with Uranium Deposit Classification," IAEA, Vienna, IAEA-TECDOC1629, 2009, p. 12.

[7] M. Lassere, "Cameroun Mise en Evidence Radiométrique de Deux Séries d'Embréchites au Sein de la Zone Mobile de l'Afrique Centrale," $10^{\text {ème }}$ Colloque de Géologie Africaine, Montpellier, 25-27 Avril 1979, p. 59.

[8] M. Lassere and D. Soba, "Migmatisation d'Age Panafricain au Sein des Formations Camerounaises Appartenant à la Zone Mobile de l'Afrique Centrale," Compte Rendu Sommaire Société Géologique de France, Vol. 2, 1979, pp. 64-69.

[9] B. Bessoles and R. Trompette, "Géologie de l'Afrique, la Chaîne Panafricaine, Zone Mobile d'Afrique Centrale (Partie Sud et Zone Mobile Soudanaise)," Mémoires du Bureau de Recherches Géologiques et Minières, Vol. 92, 1980.

[10] P. Affaton, M. A. Rahaman, R. Trompette and J. Sougy, "The Dahomeyide Orogen, Tectonothermal Evolution and Relationships with the Volta Basin," In: R. D. Dallmeyer and J. P. Lécorché, Eds., The West African Orogens and Circum-Atlantic Correlatives, Springer-Verlag, Berlin, 1991, pp. 107-122.

[11] V. Ngako, P. Affaton and E. Njonfang, "Pan-African Tectonics in the Northern Cameroon, Implication for the History of Western Gondwana," Gondwana Research, Vol. 14, No. 3, 2008, pp. 509-522. 
doi:10.1016/j.gr.2008.02.002

[12] D. Küster and J. P. Liégeois, "Sr, Nd Isotopes and Geochemistry of the Bayuda Desert High-Grade Metamorphic Basement (Sudan), an Early Pan-African Oceanic Convergent Margin, Not the Edge of the East Saharan Ghost Craton?" Precambrian Research, Vol. 109, No. 1-2, 2001, pp. 1-23. doi:10.1016/S0301-9268(00)00147-9

[13] V. Ngako, "Les Deformations Continentales Panafricaines en Afrique Centrale, Résultat d'un Poinçonnement de Type Himalayen," Thèse de Doctorat d'Etat, Université de Yaoundé I, Yaoundé, 1999.

[14] S. F. Toteu, "Geochemical Characterization of the main Petrographical and Structural Units of Northern Cameroon, Implication for Panafrican Evolution," Journal of African Earth Sciences, Vol. 10, No. 4, 1990, pp. 615-624. doi:10.1016/0899-5362(90)90028-D

[15] J. Penaye, A. Kröner, S. F. Toteu, W. R. Van Schmus and J. C. Doumnang, "Evolution of the Mayo Kebbi Region as Revealed by Zircon Dating: An Early (ca. $740 \mathrm{Ma}$ ) Pan-African Magmatic Arc in Southwestern Chad," Journal of African Earth Sciences, Vol. 44, No. 4-5, 2006, pp. 530-542. doi:10.1016/j.jafrearsci.2005.11.018

[16] S. F. Toteu, J. Penaye, E. Deloule, W. R. Van Schmus and R. Tchameni, "Diachronous Evolution of VolcanoSedimentary Basins North of the Congo Craton, Insights from U-Pb Ion Microprobe Dating of Zircons from the Poli, Lom and Yaounde' Groups (Cameroon)," Journal of African Earth Sciences, Vol. 44, No. 4-5, 2006, pp. 428442. doi:10.1016/j.jafrearsci.2005.11.011

[17] W. R. Fitches, A. C. Ajibade, I. G. Egbuniwe, R. W. Holt and J. B. Wright, "Late Proterozoic Schist Belts and Plutonism in NW Nigeria," Journal of the Geological Society, Vol. 142, No. 2, 1985, p. 319. doi:10.1144/gsigs.142.2.0319

[18] R. Caby, "The Pan-African Belt of West Africa from the Saharan Desert, the Gulf of Benin," In: J. P. Schaer and J. Rodgers, Eds, Antonony of Mountain Ranges, Princeton Univeristy Press, Princeton, 1987.

[19] R. Caby, "Les Terrains Précambrien du Bénin, Nigéria et Nord-Est Brésil et les Connections Sud-Atlantiques au Protérozoïque Supérieur," International Meeting on Proterozoic Geology and Tectonics of High-Grade Terrains, Ile-Ife, Nigeria, Program and Lecture Series, 1988.

[20] S. F. Toteu, A. Michard, J. M. Bertrand and G. Rocci, "U-Pb Dating of Precambrian Rocks from Northern Cameroon, Orogenic Evolution and Chronology of the PanAfrican Belt of Central Africa," Precambrian Research, Vol. 37, No. 1, 1987, pp. 71-87. doi:10.1016/0301-9268(87)90040-4

[21] S. F. Toteu, J. Macaudière, J. M. Bertrand and D. Dautel, "Metamorphism Zircon from North Cameroon, Implications for the Pan-African Evolution of Central Africa," Geologishe Rundschau, Vol. 79, No. 3, 1990, pp. 777-788. doi:10.1007/BF01879214

[22] C. Castaing, C. Triboulet, J. L. Feybesse and P. Chèvremont, "Tectonometamorphism Evolution of Ghana, Togo and Benin in the Light of the Pan-African Brasiliano Orogeny," Tectonophysics, Vol. 218, No. 4, 1993, pp. 323-342. doi:10.1016/0040-1951(93)90322-B
[23] C. Castaing, J. L. Feybesse, D. Thiéblemont, C. Triboulet and $\mathrm{P}$. Chèvremont, "Palaeogeographical Reconstitutions of the Pan-African/Brasiliano Orogen, Closure of an Oceanic Domain or Intracontinental Convergence between Major Blocks?" Precambrian Research, Vol. 69, 1994, pp. 327-344. doi:10.1016/0301-9268(94)90095-7

[24] R. Trompette, “Geology of Western Gondwana (2000 $500 \mathrm{Ma})$, PanAfrican-Brasiliano Aggregation of South America and Africa," A. A. Balkema Press, Rotterdam, 1994.

[25] J. L. Poidevin, "La Tectonique Panafricaine à la Bordure Nord du Craton Congolais, l'Orogenèse des 'Oubanguides',"12th Colloque on African Geology, Bruxelles, 1983, p. 75.

[26] P. Jegouzo, "Evolution Structurale du Sud-ouest Cameroun durant l'Orogénèse Panafricaine, Associations de Tectoniques Cisaillantes et Chevauchante," Colloque CNRS, Chevauchement et Déformation, Toulouse, 1984, p. 23.

[27] J. P. Nzenti, P. Barbey, P. Jegouzo and C. Moreau, "Un Nouvel Exemple de Ceinture Granulitique dans une Chaine Proterozoïque de Collision, Les Migmatites Yaoundé au Cameroun," Comptes Rendus Académie Sciences Paris, Vol. 299, 1984, pp. 1197-1199.

[28] C. Pin and J. L. Poidevin, "U-Pb Zircon Evidence for a Pan-African Granulite Facies Metamorphism in the Central African Republic. A New Interpretation of the HighGrade Series of the Northern Border of the Congo Craton," Precambrian Research, Vol. 36, No. 3-4, 1987, pp. 303-312. doi:10.1016/0301-9268(87)90027-1

[29] S. F. Toteu, W. R. Van Schmus, J. Penaye and A. Michard, "New U-Pb and Sm-Nd Data from North-Central Cameroon and Its Bearing on the Pre-Pan-African History of Central Africa," Precambrian Research, Vol. 108, No. 1-2, 2001, pp. 45-73. doi:10.1016/S0301-9268(00)00149-2

[30] Y. H. Poudjom-Djomani, J. M. Nnange, M. Diament, C. J. Ebinger and D. J. Fairhead, "Effective Elastic Thickness and Crustal Thickness Variations in West Central Africa Inferred from Gravity," Journal of Geophysical Research, Vol. 100, No. B11, 1995, pp. 22047-22070. doi:10.1029/95JB01149

[31] U. O. Njel, "Paléogéographie d'un Segment de l'Orogenèse Panafricaine, la Ceinture Volcano-Sédimentaire de Poli (Nord Cameroun)," Compte Rendu de l' Académie des Sciences, Vol. 30, 1986, pp. 1737-1742.

[32] Y. Le Fur, "Les Indices de Cuivre du Groupe Volcano Sédimentaire de Poli (Cameroun),"Bulletin du BRGM, Vol. 6, 1971, pp. 79-91.

[33] S. F. Toteu, J. F. Dumont, J. Bassahak and J. Penaye, "Complexe de Base et Séries Intermediaires Dans la Zone Mobile Panafricaine de Poli au Cameroun," Comptes Rendus de l'Académies des Sciences, Vol. 299, 1984, pp. 561-564.

[34] P. Pinna, J. Y. Calvez, A. Abessolo, J. M. Angel, T. Mekoulou-Mekoulou, G. Mananga and Y. Vernhet, "Neoproterozoic Events in the Tcholliré Area, Pan african Crustal Growth and Geodynamics in Central-Northern Cameroon (Adamawa and North Provinces)," Journal of 
African Earth Sciences, Vol. 18, No. 4, 1994, pp. 347-353. doi:10.1016/0899-5362(94)90074-4

[35] J. Penaye, "Pétrologie et Structure des Ensembles Métamorphiques au Sud Est de Poli (North Cameroon)," Unpublished Doctoral Thesis, University of Nancy (INPL), France, 1988.

[36] J. Bassahak, "Le Complexe Plutonique de Kogué (poli, nord cameroun). Petrologie-Geochimie-Petrologie Structurale; sa Place dans la Chaine Panafricaine au Nord Cameroun," Thèse de Doctorat University Nancy I, 1988.

[37] R. E. Wilson, "Basic Wrench Tectonic," American Association of Petroleum Geologists Bulletin, Vol. 57, 1973, pp. 74-96.

[38] K. G. Cox, J. D. Bell and R. J. Pankhurst, "The Interpretation of Igneous Rocks," Allen and Unwin, London, 1979.

[39] A. Peccerillo and S. R. Taylor, "Geochemistry of Eocene Calc-Alkaline Volcanic Rocks from the Kastamonu Area, Northern Turkey," Contributions to Mineralogy and Petrology, Vol. 58, No. 1, 1976, pp. 63-81. doi:10.1007/BF00384745

[40] T. N. Irvine and W. R. A. Baragar, "A Guide to the Chemical Classification of the Common Volcanic Rocks," Canadian Journal of Earth Sciences, Vol. 8, No. 5, 1971, pp. 523-548. doi:10.1139/e71-055

[41] P. D. Maniar and P. M. Piccoli, "Tectonic Discrimination of Granitoids," Geological Society of America Bulletin, Vol. 101, No. 5, 1989, pp. 635-643. doi:10.1130/0016-7606(1989)101<0635:TDOG >2.3.CO; $\underline{2}$

[42] S. J. Shand, "Eruptive Rocks, Their Genesis, Composition, Classification, and Their Relation to Ore-Deposits with a Chapter on Meteorite," John Wiley \& Sons, New York, 1943.

[43] H. De La Roche, J. Leterrier, C. P. Grande and M. Marchal, "A Classification of Volcanic and Plutonic Rocks Using R1-R2 Diagrams and Major Element Analyses its Relationships and Current Nomenclature," Chemical Geology, Vol. 29, No. 1-4, 1980, pp. 183-210. doi:10.1016/0009-2541(80)90020-0

[44] R. A. Batchelor and P. Bowden, "Petrogenetic Interpretation of Granitoid Rocks Series Using Multicationic Parameters," Chemical Geology, Vol. 48, No. 1-4, 1985, pp. 43-55. doi:10.1016/0009-2541(85)90034-8

[45] J. A. Pearce, N. B. W. Harris and A. G. Tindle, "Trace Element Discrimination Diagrams for the Tectonic Interpretation of Granitic Rocks," Journal of Petroleum, Vol. 25, No. 4, 1984, pp. 956-983.

[46] W. Boynton, "Cosmochemistry of the Rare Earth Elements, Meteorite Studies," In: P. Henderson, Ed., Rare Earth Element Geochemistry, Elsevier, 1984, pp. 63-114.

[47] F. J. Flanagan, "1972 Compilation of Data on USGS Standards," In: F. J. Flanagan, Ed., Descriptions and Analyses of Eight New USGS Rock Standards, USGS Professional Paper 840, 1976, pp. 131-183.

[48] S. R. Taylor and S. M. Mclennan, "The Continental Crust, Its Composition and Evolution," Blackwell, Oxford,
1985.

[49] W. R. Van Schmuss, "Natural Radioactivity of the Crust and Mantle Global Earth Physics-A Handbook on Physical Constants," American Geophysical Union Reference Shelf, Vol. 1, 1995, pp. 283-291.

[50] J. C. Soula, "Characteristic and Mode of Emplacement of Gneiss Domes and Plutonic Domes in Central Eastern Pyrenees," Journal of Structural Geology, Vol. 4, No. 3, 1982, pp. 313-342. doi:10.1016/0191-8141(82)90017-7

[51] B. W. Chappell and A. J. R. White, "I- and S-Type Granites in the Lachlan Fold Belt," Transactions Royal Society of Edinburgh Earth Sciences, Vol. 83, 1992, pp. 1-26.

[52] H.-J. Förster, G. Tischendorf and R. B. Trumbull, "An Evaluation of the Rb vs. ( $\mathrm{Y}+\mathrm{Nb})$ Discrimination Diagram Toinfer Tectonic Setting of Silicic Igneous Rocks" Lithos, Vol. 40, No. 2-4, 1997, pp. 261-293. doi:10.1016/S0024-4937(97)00032-7

[53] R. Emmermann, L. Daieva and J. Schneider, "Petrologic Significance of Rare Earth Distribution in Granites," Contributions to Mineralogy and Petrology, Vol. 52, No. 4, 1975, pp. 267-283. doi:10.1007/BF00401457

[54] L. A. Haskin and R. A. Schmitt, "Rare-Earth Distributions" In: P. H. Abelson, Ed., Researches in Geochemistry, John Wiley and Sons, Inc., New York, Vol. 2, 1967, pp. 235-258.

[55] V. O. Olarewaju, "REE in the Charnockitic and Associated Granitic Rocks of Ado Ekiti-Akure, SW Nigeria," In: P.O. Oluyide et al., Eds., Precambrian Geology of Nigeria, Geological Survey of Nigeria Publication, Kaduna, 1988, pp. 231-239.

[56] V. U. Ukaegbu and F. T. Beka, "Rare Earth Elements as Source Indicators of Pan African Granites from Obudu Plateau, Southern Nigeria," Chinese Journal of Geochemistry, Vol. 27, No. 2, 2008, pp. 130-134. doi:10.1007/s11631-008-0130-2

[57] G. Zhang, R. Hu, X. Bi, H. Feng, P. Shang and J. Tian, "REE Geochemical Characteristics of the No. 302 Uranium Deposit in Northern Guangdong, South China," Chinese Journal of Geochemistry, Vol. 26, No. 4, 2006, pp. 425-433. doi:10.1007/s11631-007-0425-8

[58] R. Banerjee and K. Shivkumar, "Geochemistry and Petrogenesis of Radioactive Palaeoproterazoic Granitoids of Kinwat Inlier, Nanded and Yeotmal Districts Maharashtra," Journal of the Geological Society of India, Vol. 75, No. 4, 2010, pp. 596-617. doi:10.1007/s12594-010-0054-4

[59] R. K. O’Nions and R. J. Pankhurst, "Rare-Earth Element Distribution in Archaean Gneisses and Anorthosites, Godthab Area, West Greenland," Earth and Planetary Science Letters, Vol. 22, 1974, pp. 328-338.

[60] P. O. Okeke and M. A. Meju, "Chemical Evidence for the Sedimentary Origin of Igarra Supracrustral Rocks in the Southwestern Nigeria Basement Complex," Nigeria Journal of Mining and Geology, Vol. 22, No. 2, 1985, pp. 97-104.

[61] R. Balk, "Structural Behavior of Igneous Rocks," Memoire (SAUS) Geological Society of America, Vol. 1, 1937, pp. 291-302. 
[62] G. Courrioux, "Etude d'une Evolution Magmatique et Structural dans le Contexte d'une Zone de Cisaillement Ductile Active, Exemple du Linéament Granitique Hercynien de Puentedeume (Gallice, Espagne)," Thèse $3^{\mathrm{e}}$ cycle, University Nancy I, 1984.

[63] S. C. Paterson and O. T. Tobisch, "Using Pluton Ages to Date Regional Deformation Problems with Commonly Used Criteria," Geology, Vol. 16, No. 12, 1989, pp. 11081111 .

doi:10.1130/0091-7613(1988)016<1108:UPATDR >2.3.C $\underline{\mathrm{O} ; 2}$

[64] J. L. Lagarde, "Granites Tardi Carbonifères et Déformation Crustale, l'Exemple de la Meseta Marocaine," Thèse Docteur ès Science, Rennes, 1987.

[65] J. L. Lagarde, S. Ait Omar and B. Roddaz, "Structural Characteristics of Plutons Emplaced during Weak Regional Deformation, Example from Late Carboniferous Plutons Morocco," Journal of Structural Geology, Vol. 12, No. 7, 1990, pp. 805-821. doi:10.1016/0191-8141(90)90056-5

[66] D. Gasquet, "Genèse d'un Pluton Composite TardiHercynien, le Massif de Tichka, Haut Atlas Occidental (Maroc)," Thèse Docteur ès Science, Université Henri Poincaré, 1991.

[67] J. P. Nzenti, V. Ngako, R. Kambou, J. Bassahak and U. O. Njel, "Structures Régionales de la Chaîne Panafricaine du Nord-Cameroun,"Comptes Rendus de l'Académie des Sciences, Vol. 315, 1992, pp. 209-215.

[68] J. Li, M. Zhou, X. Li, Z. Fu and Z. Li, "Structural Control on Uranium Mineralization in South China, Implication for Fluid Flow in Continental Strike Slip Faults," Science in China, Vol. 45, No. 9, 2002, pp. 851-864.

[69] J. S. Caine, R. L. Bruhn and C. B. Forster, "Internal Structure, Fault Rocks, and Inferences Regarding Deformation, Fluid Flow, and Mineralization in the Seismogenic Stillwater Normal Fault, DixieValley, Nevada," Journal of Structural Geology, Vol. 32, No. 11, 2010, pp. 1576-1589. doi:10.1016/j.jsg.2010.03.004
[70] W. H. Newhouse, "Ore Deposits as Related to Structural Features," Hafner Publishing Co., New York, London, 1942 , p. 280

[71] S. F. Cox, M. A. Knackstedt and J. Braun, "Principles of Structural Control on Permeability and Fluid Flow in Hydrothermal Systems," Reviews in Economic Geology, Vol. 14, 2001, pp. 1-24.

[72] R. H. Sibson, "Seismogenic Framework for Hydrothermal Transport and Ore Deposition," Reviews in Economic Geology, Vol. 14, 2001, pp. 25-50.

[73] S. Micklethwaite, "Mechanisms of Faulting and Fermeability Enhancement during Epithermal Mineralization, Cracow Goldfield, Australia," Journal of Structural Geology, Vol. 31, No. 3, 2009, pp. 288-300. doi:10.1016/j.jsg.2008.11.016

[74] N. C. White, M. J. Leake and S. N. McCaughey, "Epithermal Gold Deposits of the Southeastern Pacific," Journal of Geochemical Exploration, Vol. 54, No. 2, 1995, pp. 87-136. doi:10.1016/0375-6742(95)00027-6

[75] V. G. Voroshilov, "Anomalous Structures of Geochemical Fields of Hydrothermal Gold Deposits, Formation Mechanism Methods of Geometrization, Typical Models, and Forecasting of Ore Mineralization," Geology of Ore Deposits, Vol. 51, No. 1, 2009, pp. 3-19. doi:10.1134/S1075701509010012

[76] P. Alexandre, "Mineralogy and Geochemistry of Sodium Metasomatism-Related Uranium Occurrence of Aricheng South, Guyana," Mineralium Deposita, Vol. 45, No. 4, 2010, pp. 351-367. doi:10.1007/s00126-010-0278-7

[77] S. Cinelu and M. Cuney, "Sodic Metasomatism and U-Zr Mineralization, a Model Based on the Kurupung Batholith (Guyana)," Geochim Cosmochim Acta, Vol. 70, No. 18, 2006, A103.

[78] B. T. Zhang, J. Wu, Z. Qiu and Y. Liu, "On the Relationship between Hydrothermal Alteration and Uranium Enrichement," Geological Review, Vol. 38, 1990, pp. 238245. 